\title{
Uakitite, VN, a New Mononitride Mineral from Uakit Iron Meteorite (IIAB) ${ }^{\dagger}$
}

\author{
Victor V. Sharygin 1,2,3,*(D), German S. Ripp ${ }^{4}$, Grigoriy A. Yakovlev ${ }^{3}$, Yurii V. Seryotkin 1,2 (D), \\ Nikolai S. Karmanov ${ }^{1}$, Ivan A. Izbrodin ${ }^{4}$, Victor I. Grokhovsky ${ }^{3}$ and Elena A. Khromova ${ }^{4}$ \\ 1 V.S. Sobolev Institute of Geology and Mineralogy, Siberian Branch of the RAS, 3 Acad. Koptyuga pr., \\ 630090 Novosibirsk, Russia; yuvs@igm.nsc.ru (Y.V.S.); krm@igm.nsc.ru (N.S.K.) \\ 2 Department of Geology and Geophysics, Novosibirsk State University, 2 Pirogov str., \\ 630090 Novosibirsk, Russia \\ 3 ExtraTerra Consortium, Institute of Physics and Technology, Ural Federal University, 19 Mira str., \\ 620002 Ekaterinburg, Russia; yakovlev.grigoriy@gmail.com (G.A.Y.); grokh47@mail.ru (V.I.G.) \\ 4 Geological Institute, Siberian Branch of the RAS, 6a Sakhyanovoi str., 670047 Ulan-Ude, Russia; \\ ripp@ginst.ru (G.S.R.); izbrodin@ginst.ru (I.A.I.); lena.khromova.00@mail.ru (E.A.K.) \\ * Correspondence: sharygin@igm.nsc.ru; Tel.: +7-383-330-80-84 \\ + The paper was presented at the 81st Annual Meeting of the Meteoritical Society in Moscow, Russia, \\ 22-27 July 2018.
}

Received: 22 January 2020; Accepted: 6 February 2020; Published: 10 February 2020

\begin{abstract}
Uakitite was observed in small troilite-daubréelite ( \pm schreibersite) inclusions (up to $100 \mu \mathrm{m}$ ) and in large troilite-daubréelite nodules (up to $1 \mathrm{~cm}$ ) in Fe-Ni-metal (kamacite) of the Uakit iron meteorite (IIAB), Republic of Buryatia, Russia. Such associations in the Uakit meteorite seemed to form due to high-temperature $\left(>1000^{\circ} \mathrm{C}\right)$ separation of Fe-Cr-rich sulfide liquid from Fe-metal melt. Most inclusions represent alternation of layers of troilite and daubréelite, which may be a result of solid decay of an initial Fe-Cr-sulfide. These inclusions are partially resorbed and mainly located in fissures of the meteorite, which is now filled with magnetite, and rarely other secondary minerals. Phase relations indicate that uakitite is one of the early minerals in these associations. It forms isometric (cubic) crystals (in daubréelite) or rounded grains (in schreibersite). The size of uakitite grains is usually less than $5 \mu \mathrm{m}$. It is associated with sulfides (daubréelite, troilite, grokhovskyite), schreibersite and magnetite. Carlsbergite $\mathrm{CrN}$, a more abundant nitride in the Uakit meteorite, was not found in any assemblages with uakitite. Physical and optical properties of uakitite are quite similar to synthetic VN: yellow and transparent phase with metallic luster; Mohs hardness: 9-10; light gray color with a pinky tint in reflected light; density (calc.) $=6.128 \mathrm{~g} / \mathrm{cm}^{3}$. Uakitite is structurally related to the osbornite group minerals: carlsbergite $\mathrm{CrN}$ and osbornite TiN. Structural data were obtained for three uakitite crystals using the electron backscatter diffraction (EBSD) technique. Fitting of the EBSD patterns for a synthetic VN model (cubic, $F m-3 m, a=4.1328(3) \AA ; V=70.588(9) \AA^{3} ; Z=4$ ) resulted in the parameter MAD $=0.14-0.37^{\circ}$ (best-good fit). Analytical data for uakitite $(n=54$, in wt. \%) are: V, 71.33; Cr, 5.58; Fe, 1.56; N, 21.41; Ti, below detection limit $(<0.005)$. The empirical formula $\left(\mathrm{V}_{0.91} \mathrm{Cr}_{0.07} \mathrm{Fe}_{0.02}\right)_{1.00} \mathrm{~N}_{1.00}$ indicates that chromium incorporates in the structure according to the scheme $\mathrm{V}^{3+} \rightarrow \mathrm{Cr}^{3+}$ (up to 7 mol. \% of the carlsbergite end-member).
\end{abstract}

Keywords: uakitite; carlsbergite; osbornite group; troilite; daubréelite; Uakit meteorite; IIAB iron; Buryatia

\section{Introduction}

Nitrides and oxynitrides are very scarce minerals in natural conditions. Most of them (carlsbergite CrN, osbornite TiN, roaldite $(\mathrm{Fe}, \mathrm{Ni})_{4} \mathrm{~N}$, nierite $\alpha-\mathrm{Si}_{3} \mathrm{~N}_{4}$, sinoite $\left.\mathrm{Si}_{2} \mathrm{~N}_{2} \mathrm{O}\right)$ occur solely in extraterrestrial 
environments, in different types of meteorites [1-20]. Only siderazot $\mathrm{Fe}_{5} \mathrm{~N}_{2}$, which is "grandfathered" and questionable mineral (there is no modern confirmation for composition), appears to be terrestrial in origin, and was only identified in fumaroles associations of the Etna and Somma-Vesuvius volcanic complexes [21-23]. A new mineral, uakitite VN, was observed as an accessory phase in the Uakit iron meteorite and is the sixth nitride mineral which is found in meteorites [24-28]. The mineral was approved by the Commission on New Minerals, Nomenclature and Classification (CNMNC) of the International Mineralogical Association (IMA) as a new mineral species in May 2018 (IMA 2018-003) [26].

In contrast with the natural phase, synthetic VN is a well-known compound since the 1920s [29] and widely used in the different branches of industry. Like other transition metal nitrides (CrN, $\mathrm{TiN}, \mathrm{ZrN}, \mathrm{NbN}$, etc.), it has long been of interest due to its excellent physical and chemical properties, such as high melting point, metallic conductivity, good chemical stability and high mechanical hardness. Owing to these properties, synthetic VN has a wide range of technological applications, e.g., as abrasive material, alloying component, wear and corrosion-resistant coatings, field emitter, supercapacitors, superconductors and buffer layers in microelectronics [30-45]. Intermediate compositions of TiN-CrN-VN have higher hardness than that for simple compounds [46,47].

\section{History of the Uakit Meteorite}

This iron meteorite was found summer 2016 by a gold prospector group during excavation works on river terrace (stream Mukhtunnyi, left feeder of the Uakit River) in $4 \mathrm{~km}$ west of the Uakit settlement, Baunt Evenk district, northern part of Republic of Buryatia, Russia (latitude: $55^{\circ} 29^{\prime} 47.50^{\prime \prime}$ N; longitude: $\left.113^{\circ} 33^{\prime} 47.98^{\prime \prime} \mathrm{E}\right)$. At present, one sample $(3.96 \mathrm{~kg}$, Figure 1) of the Uakit meteorite was identified. However, the information about the finding of larger iron meteorite mass $(\approx 50 \times 50 \mathrm{~cm})$ is known among prospectors around Uakit. The date of fall is unknown. During summer 2016, the $3.96 \mathrm{~kg}$ meteorite sample was passed to Oleg Yu. Korshunov (Ulan-Ude), who then handed several cut-offs in the Geological Institute (GI, SB RAS, Ulan-Ude, Russia) for expert examination. Later, some fragments of the meteorite were passed in V.S. Sobolev Institute of Geology and Mineralogy (IGM, SB RAS, Novosibirsk, Russia) for mineralogical studies in detail.

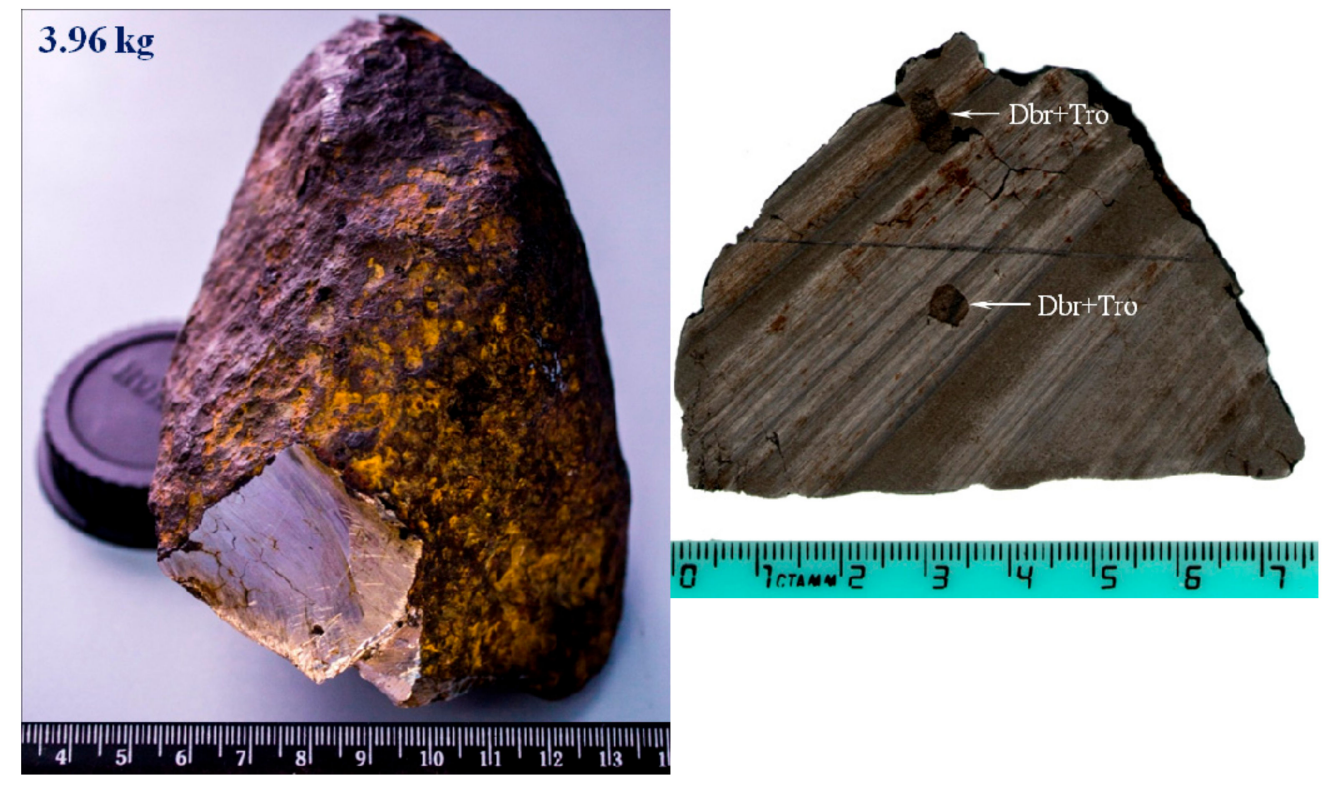

Figure 1. General view of the Uakit iron meteorite (IIAB) and one of cut-offs with troilite-daubréelite nodules. Symbols: Dbr + Tro-troilite-daubréelite nodule.

The Uakit iron meteorite (IIAB) was approved on the 28 June 2017 by the Meteorite Nomenclature Committee (see Meteoritical Bulletin Database). The cut-off fragments of the meteorite are now 
deposited in the meteorite collections of the Central Siberian Geological Museum of the IGM (CSGM IGM, type specimens: $70.3 \mathrm{~g}$ and $17.5 \mathrm{~g}$ cut-offs, SB RAS, Novosibirsk, Russia), the Museum of the Buryatian Scientific Centre (51.2 and 18 g cut-offs, MBSC SB RAS, Ulan-Ude, Russia), ExtraTerra Consortium Lab, Ural Federal University (1.6 g cut-off, Ekaterinburg, Russia) and A.E. Fersman Mineralogical Museum ( $<1 \mathrm{~g}$ cut-off, Moscow, Russia).

As a result of detailed mineralogical studies two new minerals, were identified in this meteorite: uakitite VN (IMA 2018-003) [26] and grokhovskyite $\mathrm{CuCrS}_{2}$ (IMA 2019-065) [48]. In this paper, we provide a detailed description of uakitite. Some data on this mineral in the Uakit meteorite were reported in a few previous publications [24-26,48,49]. The name of the mineral is given after the meteorite. The holotype specimens of uakitite are on display in the meteorite collections of the CSGM IGM, SB RAS, Novosibirsk (registration numbers 52 and 52b, meteorite Uakit) and in the MBSC, SB RAS, Ulan-Ude (registration number Uakit-MBSC435/G84).

\section{Analytical Methods}

Polished fragments were used for optical examination of the Uakit meteorite in reflected light. The identification of all minerals was based on energy-dispersive spectra (EDS), backscattered electron (BSE) images and elemental mapping (EDS system), using a TESCAN MIRA 3MLU scanning electron microscope equipped with an INCA Energy 450 XMax 80 microanalysis system (Oxford Instruments Ltd., Abingdon, UK) at the IGM, Novosibirsk, Russia, and a LEO-1430 scanning electron microscope equipped with an INCA Energy-300 EDS microanalysis system at the GI, Ulan-Ude, Russia. The instruments were operated at an accelerating voltage of $20 \mathrm{kV}$ and a probe current of $1 \mathrm{nA}$ in high-vacuum mode. EDS analyses of uakitite and other minerals were done at an accumulation time of 20-40 s. The following simple compounds and metals were used as reference standards for most of the elements: $\mathrm{Ca}_{2} \mathrm{P}_{2} \mathrm{O}_{7}(\mathrm{P}), \mathrm{Cr}_{2} \mathrm{O}_{3}(\mathrm{Cr})$, pyrite $(\mathrm{S}), \mathrm{Si}_{3} \mathrm{~N}_{4}$ or $\mathrm{BN}(\mathrm{N})$, metallic Ti, $\mathrm{Fe}, \mathrm{Cu}, \mathrm{Zn}, \mathrm{Mn}, \mathrm{Ni}$, $\mathrm{V}$ and others. Correction for matrix effects was done using the XPP algorithm, implemented in the software of the microanalysis system. Metallic Co served for quantitative optimization (normalization to probe current and energy calibration of the spectrometer). The overlapping of $\operatorname{VK} \beta$ and $\mathrm{CrK} \alpha$ was specially checked using the $\mathrm{Cr}_{2} \mathrm{O}_{3}$ and metallic $\mathrm{V}$ standards.

Electron microprobe analyses (EMPA) in wavelength-dispersive (WDS) mode were performed for metals and sulfides, which are associated with uakitite in the Uakit iron meteorite, using a JXA-8100 microprobe (Jeol Ltd., Tokyo, Japan) at IGM. Grains (sizes $>5 \mu \mathrm{m}$ ) previously analyzed by EDS were selected for this purpose. The operating conditions were as follows: beam diameter of 1-2 $\mu \mathrm{m}$, accelerating voltage of $20 \mathrm{kV}$, beam current of $50 \mathrm{nA}$ and counting time of $10(5+5) \mathrm{s}$. The following standards were used for two microprobe sessions: natural spessartite (Mn), synthetic $\mathrm{FeS}$ or $\mathrm{FeS}_{2}(\mathrm{~S})$, Fe-metal or FeS (Fe), Fe-Ni-Co alloy (Ni and $\mathrm{Co}$ ), $\mathrm{GaP}(\mathrm{P}), \mathrm{Cr}_{2} \mathrm{O}_{3}(\mathrm{Cr}), \mathrm{ZnS}(\mathrm{Zn}), \mathrm{CuFeS}_{2}(\mathrm{Cu})$ and $\mathrm{V}_{2} \mathrm{O}_{5}(\mathrm{~V})$. Correction for matrix effects was done using a PAP routine [50]. The precision of analysis for major elements was better than $2 \%$ relative. The detection limits for elements were (in ppm): $\mathrm{S}$, 115-208; Fe, 132-188; Ni, 119-130; Co, 55-102; P, 167-185; Mn, 184-203; Cr, 146-170; Zn, 108-119; Cu, $108 ; \mathrm{V}, 164$.

Electron backscatter diffraction (EBSD) studies were provided for three grains of uakitite. Samples containing uakitite and intended for EBSD studies were subjected to polishing by BuehlerMasterMet2 non-crystallizing colloidal silica suspension $(0.02 \mu \mathrm{m})$. EBSD measurements were carried out by means of an FE-SEM ZEISS SIGMA VP scanning electron microscope equipped with an Oxford Instruments Nordlys HKL EBSD detector, operated at $20 \mathrm{kV}$ and $1.4 \mathrm{nA}$ in focused beam mode with a $70^{\circ}$ tilted stage at Institute of Physics and Technology, Ural Federal University, Ekaterinburg, Russia. Structural identification of uakitite was performed by matching its EBSD patterns with the reference structural models using program FLAMENCO. 


\section{General Description of the Uakit Meteorite}

The $3.96 \mathrm{~kg}$ mass of the meteorite is oval $(10 \times 10 \times 7 \mathrm{~cm})$. The exterior part is covered by thin crust of brown to yellow-brown secondary products (mainly, different Fe-rich hydroxides, Figure 1). Polished and then etched surfaces of the meteorite cut-offs show the presence of large $(\approx 2 \mathrm{~cm})$ kamacite crystals with evident Neumann lines; no Widmannstatten pattern is observed (Figure 2). Weathering and fusion crusts are less than $1 \mathrm{~mm}$ in the exterior. Sometimes they extend together along some fractures of the outer part, but their abundance is low (Figure 1). The shock stage is medium and mainly fixed by shifting of blocks in some schreibersite and carlsbergite crystals and by Neumann lines.

The bulk composition of the meteorite is (ICP-MS, IGM, $n=2$ ): $\mathrm{Ni}=5.47$; $\mathrm{Co}=0.45$ (both in wt. \%); $\mathrm{Si}=732-886 ; \mathrm{P}=989-1063 ; \mathrm{Cr}=127-139 ; \mathrm{Cu}=149-294 ; \mathrm{V}=0.10-0.24 ; \mathrm{Zn}=6-68 ; \mathrm{Ga}=49-50$; $\mathrm{Ge}=203-215 ; \mathrm{As}=2.4-3.0 ; \mathrm{Mo}=5.1-5.9 ; \mathrm{Ru}=18.7 ; \mathrm{Rh}=2.0 ; \mathrm{Pd}=1.26-1.40 ; \mathrm{Sn}=6.9-44 ; \mathrm{Sb}=0.064-0.10$; $\mathrm{W}=3.0 ; \mathrm{Re}=1.67-1.76 ; \mathrm{Ir}=20 ; \mathrm{Pt}=24 ; \mathrm{Au}=0.51-0.53$ (in ppm) [25]. The Uakit iron meteorite is structurally and geochemically characterized to be a hexahedrite, IIAB group, with tendency to the IIA subgroup.

Fe-Ni-metal (kamacite) is the main mineral of the meteorite ( $\approx 93-98$ vol. \%, Figure 1$)$. Minor and accessory primary minerals are represented by schreibersite (rhabdite), nickelphosphide, taenite, plessite (taenite + kamacite + tetrataenite), cohenite, tetrataenite, daubréelite, kalininite, troilite, carlsbergite, sphalerite, uakitite, copper, grokhovskyite and an unidentified Mo-dominant phase $(<0.5 \mu \mathrm{m}$, molybdenite or hexamolybdenum $(\mathrm{Mo}, \mathrm{Ru}, \mathrm{Fe})$ or $\mathrm{Mo}$ or $\mathrm{MoC}$, according to recent meteorite minerals list in [19]) (Figures 1-3).
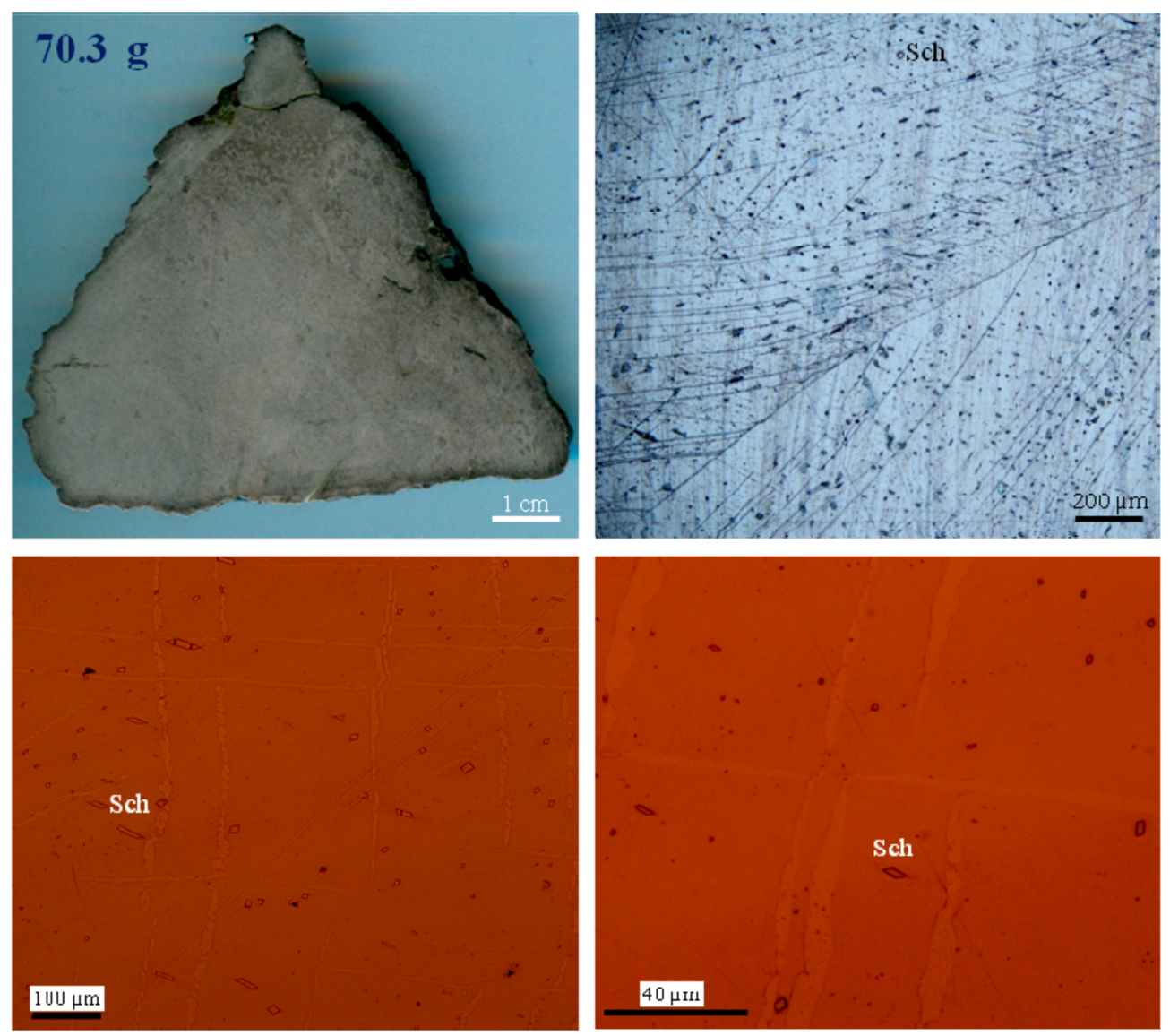

Figure 2. Neumann lines and oriented schreibersite grains (Sch) in Fe-Ni-metal (kamacite), Uakit meteorite (IIAB), images in ordinary and reflected light. Upper images: samples were etched by nital. The upper left image is for type specimen (70.3 g cut-off) of the Uakit meteorite from the CSGM IGM, SB RAS, Novosibirsk. 
The appearance of Ni-rich magnetite, pentlandite, heazlewoodite, awaruite to native nickel, unidentified $\mathrm{Ni}$-Fe-Cr-sulfide as well as Ni-rich goethite, akaganeite, Ni-rich siderite, Ca-Fe-carbonates, gypsum and unidentified hydrated Fe-rich phosphate and Ca-Fe-sulfate is related to different stages of the terrestrial alteration [24-26,48,49]. Magnetite, pentlandite, awaruite-nickel and heazlewoodite seem to be related to the high-temperature alteration (fusion crust?), whereas goethite and other Fe-hydroxides to low-temperature weathering products. The chemical composition of the principal minerals in the Uakit iron meteorite is listed in Table 1.

The presence of large sulfide nodules (up to $1 \mathrm{~cm}$ ) of troilite-daubréelite composition is common in the Uakit meteorite (Figure 1). Cohenite occurs mainly near the exterior and forms skeletal crystals up to $0.5 \mathrm{~mm}$; sometimes it is observed on the boundary between kamacite grains. Ni-poorer taenite (<33 wt. \% Ni), Ni-rich kamacite (>6.3 wt. \% Ni) and Fe-rich nickelphosphide are most typical for the cohenite-containing associations.
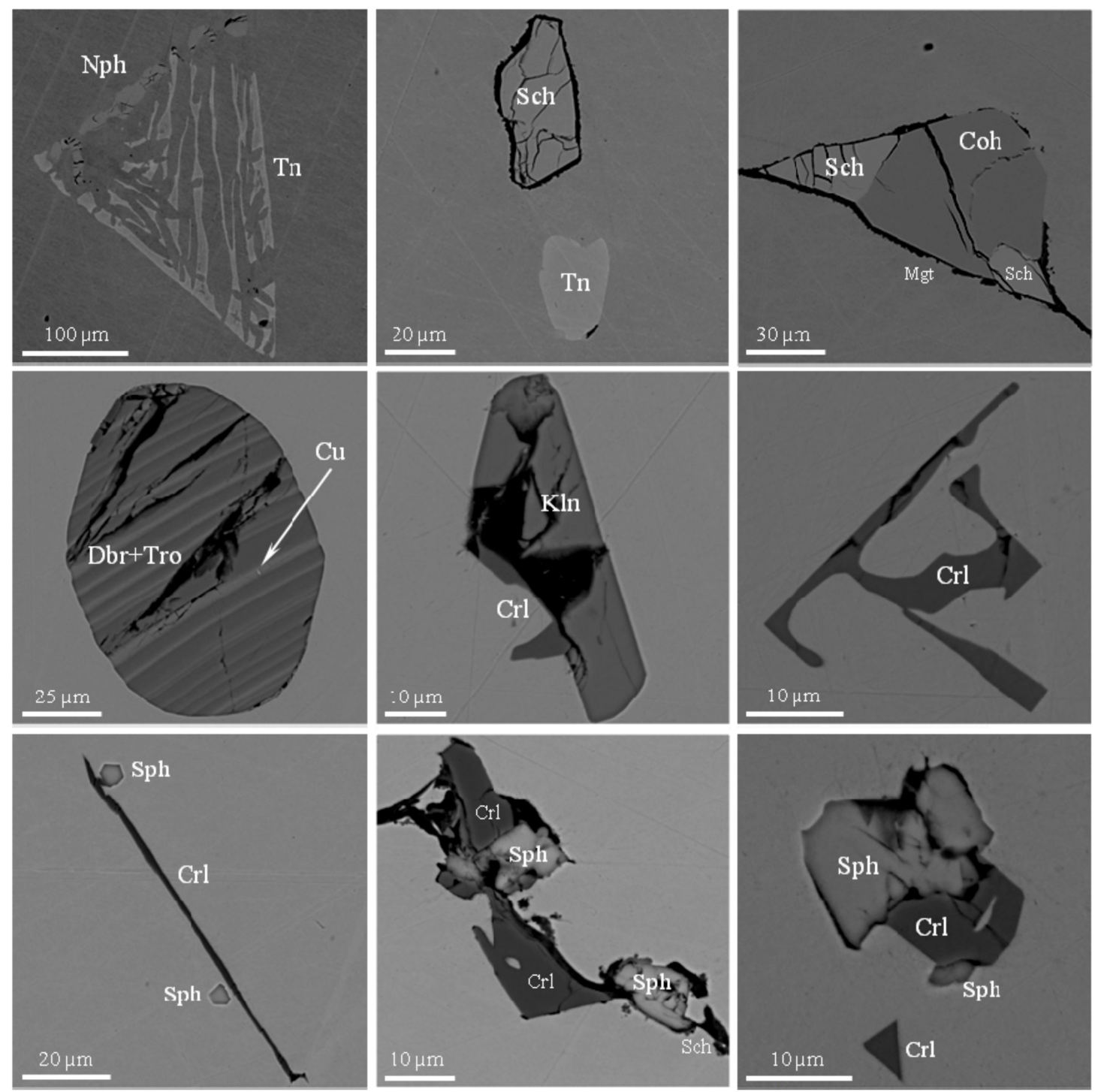

Figure 3. Mono- and polymineralic inclusions and globules in Fe-Ni-metal (kamacite), Uakit meteorite (IIAB), BSE images. Symbols: Dbr—daubréelite; Sch—schreibersite; Nph—nickelphosphide; $\mathrm{Tn}$-taenite; Coh-cohenite; Tro-troilite; $\mathrm{Cu}$-native copper; $\mathrm{Crl}$-carlsbergite; $\mathrm{Kln}$-kalininite; Sph—sphalerite; Mgt—magnetite. 
Table 1. Chemical composition (WDS, wt. \%) of the essential minerals in the Uakit iron meteorite.

\begin{tabular}{|c|c|c|c|c|c|c|c|c|c|c|c|c|c|c|c|c|c|c|c|c|c|c|c|}
\hline Mineral & & $\mathrm{Fe}$ & Mn & $\mathrm{Ni}$ & Co & $\mathrm{Zn}$ & $\mathrm{Cu}$ & $\mathrm{Cr}$ & $\mathrm{V}$ & $\mathbf{P}$ & $\mathrm{S}$ & Sum & Formula & $\mathrm{Fe}$ & Mn & $\mathrm{Ni}$ & Co & $\mathrm{Zn}$ & $\mathrm{Cu}$ & $\mathrm{Cr}$ & $\mathrm{V}$ & $\mathbf{P}$ & $S$ \\
\hline & & & & & & & & & & & & & based on & & & & & & & & & & \\
\hline Kamacite & $\begin{array}{c}n=34 \\
\mathrm{sd}\end{array}$ & $\begin{array}{c}93.46 \\
0.56\end{array}$ & n.d. & $\begin{array}{l}6.09 \\
0.51\end{array}$ & $\begin{array}{l}0.48 \\
0.05\end{array}$ & n.d. & n.d. & n.d. & n.d. & $\begin{array}{l}0.06 \\
0.04\end{array}$ & n.d. & 100.09 & 1 ion & 0.94 & & 0.06 & 0.00 & & & & & 0.00 & \\
\hline Taenite & $\begin{array}{c}n=19 \\
\text { sd }\end{array}$ & $\begin{array}{c}67.63 \\
6.48\end{array}$ & n.d. & $\begin{array}{c}32.12 \\
6.54\end{array}$ & $\begin{array}{l}0.13 \\
0.05\end{array}$ & n.d. & $\begin{array}{l}0.23 \\
0.09\end{array}$ & n.d. & n.d. & n.d. & n.d. & 100.10 & 1 ion & 0.69 & & 0.31 & 0.00 & & 0.00 & & & & \\
\hline Tetrataenite & $\begin{array}{c}n=14 \\
\mathrm{sd}\end{array}$ & $\begin{array}{c}42.66 \\
1.08\end{array}$ & n.d. & $\begin{array}{c}56.96 \\
1.22\end{array}$ & $\begin{array}{l}0.01 \\
0.02\end{array}$ & n.d. & $\begin{array}{l}0.24 \\
0.10\end{array}$ & $\begin{array}{l}0.17 \\
0.15\end{array}$ & n.d. & n.d. & n.d. & 100.04 & 1 ion & 0.44 & & 0.56 & 0.00 & & 0.00 & 0.00 & & & \\
\hline Cohenite & $\begin{array}{c}n=18 \\
\text { sd }\end{array}$ & $\begin{array}{c}91.64 \\
0.29\end{array}$ & n.d. & $\begin{array}{l}1.57 \\
0.06\end{array}$ & $\begin{array}{l}0.08 \\
0.02\end{array}$ & n.d. & n.d. & $\begin{array}{l}0.12 \\
0.05\end{array}$ & n.d. & n.d. & n.d. & 93.41 & 3 ions & 2.95 & & 0.05 & 0.00 & & & 0.00 & & & \\
\hline Schreibersite & $\begin{array}{c}n=19 \\
\text { sd }\end{array}$ & $\begin{array}{c}50.47 \\
3.56\end{array}$ & n.d. & $\begin{array}{c}34.25 \\
3.51\end{array}$ & $\begin{array}{l}0.09 \\
0.02\end{array}$ & n.d. & n.d. & $\begin{array}{l}0.04 \\
0.09\end{array}$ & n.d. & $\begin{array}{c}15.16 \\
0.08\end{array}$ & $\begin{array}{l}0.01 \\
0.02\end{array}$ & 100.03 & 4 ions & 1.83 & & 1.18 & 0.00 & & & 0.00 & & 0.99 & 0.00 \\
\hline Nickelphosphide & $\begin{array}{c}n=12 \\
\mathrm{sd}\end{array}$ & $\begin{array}{c}39.43 \\
2.81\end{array}$ & n.d. & $\begin{array}{c}45.02 \\
2.74\end{array}$ & $\begin{array}{l}0.05 \\
0.04\end{array}$ & n.d. & n.d. & $\begin{array}{l}0.25 \\
0.37\end{array}$ & n.d. & $\begin{array}{c}15.17 \\
0.06\end{array}$ & $\begin{array}{l}0.05 \\
0.04\end{array}$ & 99.97 & 4 ions & 1.43 & & 1.56 & 0.00 & & & 0.01 & & 0.99 & 0.00 \\
\hline Daubréelite & $\begin{array}{c}n=39 \\
\text { sd }\end{array}$ & $\begin{array}{c}19.22 \\
0.84\end{array}$ & $\begin{array}{l}0.23 \\
0.20\end{array}$ & $\begin{array}{l}0.07 \\
0.09\end{array}$ & $\begin{array}{l}0.01 \\
0.02\end{array}$ & $\begin{array}{l}0.48 \\
0.53\end{array}$ & $\begin{array}{l}0.07 \\
0.03\end{array}$ & $\begin{array}{c}35.47 \\
0.63\end{array}$ & $\begin{array}{l}0.01 \\
0.02\end{array}$ & n.d. & $\begin{array}{c}44.42 \\
0.11\end{array}$ & 99.91 & 7 ions & 0.99 & 0.01 & 0.00 & 0.00 & 0.02 & 0.00 & 1.97 & 0.00 & & 4.00 \\
\hline Kalininite & $\begin{array}{c}n=11 \\
\mathrm{sd}\end{array}$ & $\begin{array}{c}10.15 \\
0.92\end{array}$ & $\begin{array}{l}0.04 \\
0.00\end{array}$ & n.d. & n.d. & $\begin{array}{c}11.50 \\
0.91\end{array}$ & n.d. & $\begin{array}{c}34.55 \\
0.20\end{array}$ & n.d. & n.d. & $\begin{array}{c}43.68 \\
0.05\end{array}$ & 99.92 & 7 ions & 0.53 & 0.00 & & & 0.52 & & 1.95 & & & 4.00 \\
\hline Troilite & $\begin{array}{c}n=13 \\
\text { sd }\end{array}$ & $\begin{array}{c}62.42 \\
0.32\end{array}$ & n.d. & $\begin{array}{l}0.16 \\
0.29\end{array}$ & n.d. & n.d. & $\begin{array}{l}0.12 \\
0.03\end{array}$ & $\begin{array}{l}0.67 \\
0.18\end{array}$ & $\begin{array}{l}0.01 \\
0.02\end{array}$ & n.d. & $\begin{array}{c}36.53 \\
0.07\end{array}$ & 99.92 & 2 ions & 0.98 & & 0.00 & & & 0.00 & 0.01 & & & 1.00 \\
\hline Pentlandite & $\begin{array}{c}n=9 \\
\text { sd }\end{array}$ & $\begin{array}{c}32.87 \\
3.48\end{array}$ & n.d. & $\begin{array}{c}31.75 \\
2.79\end{array}$ & $\begin{array}{l}1.39 \\
1.13\end{array}$ & n.d. & $\begin{array}{l}0.01 \\
0.02\end{array}$ & $\begin{array}{l}0.68 \\
0.16\end{array}$ & $\begin{array}{l}0.02 \\
0.02\end{array}$ & n.d. & $\begin{array}{c}33.27 \\
0.05\end{array}$ & 99.98 & 17 ions & 4.54 & & 4.17 & 0.18 & & 0.00 & 0.10 & 0.00 & & 8.00 \\
\hline Heazlewoodite & $\begin{array}{c}n=5 \\
\text { sd }\end{array}$ & $\begin{array}{l}5.68 \\
0.70\end{array}$ & n.d. & $\begin{array}{c}64.77 \\
2.20\end{array}$ & $\begin{array}{l}1.57 \\
1.27\end{array}$ & n.d. & n.d. & $\begin{array}{l}0.45 \\
0.29\end{array}$ & $\begin{array}{l}0.02 \\
0.02\end{array}$ & n.d. & $\begin{array}{c}27.45 \\
1.02\end{array}$ & 99.94 & 5 ions & 0.24 & & 2.63 & 0.06 & & & 0.02 & 0.00 & & 2.04 \\
\hline
\end{tabular}


Schreibersite $(20-100 \mu \mathrm{m})$ and carlsbergite $(1-10 \mu \mathrm{m})$ elongated crystals are sometimes oriented in one or more directions within large kamacite grains (Figure 2). In addition to the above assemblages, the presence of rounded sulfide globules (mainly daubréelite + troilite, up to $100 \mu \mathrm{m}$ ), plessite isolations (taenite + kamacite + tetrataenite) and mono- or polymineralic inclusions are very common in kamacite (Figures 3-7). Sulfide globules with a "layered structure" (alternating layers of troilite and daubréelite as a possible result of solid decay of initial high-temperature $\mathrm{Fe}-\mathrm{Cr}$-sulfide) are more widespread than those without layering. Namely, in such associations two new minerals (uakitite, grokhovskyite), Fe-rich kalininite (first finding in meteorites), copper and sphalerite were identified in this meteorite (Figure 3).

\section{Morphology, Optical and Physical Properties of Uakitite}

At present, uakitite is observed only in small troilite-daubréelite ( \pm schreibersite) globules with "layered structure" hosted by kamacite and in large troilite-daubréelite nodules (Figures 1 and 4-8). It forms isometric (cubic) crystals (in daubréelite) or rounded grains (in schreibersite). The size of uakitite grains is commonly less than $5 \mu \mathrm{m}$ (Figures 4-8); the largest detected crystal is $5 \times 5 \mu \mathrm{m}$ (Figures 4 and 5). Twinning was not observed. Uakitite from sulfide globules is associated with sulfides (daubréelite, troilite, grokhovskyite), schreibersite and magnetite. In large sulfide nodules, it is confined to their outer margins (Figure 7). In general, both globules and nodules exhibit varying degrees of partial resorption due to alteration processes. Carlsbergite $\mathrm{CrN}$ is a more abundant nitride in the Uakit meteorite, but it was not found yet in any assemblages with uakitite. In addition to polymineralic inclusions (Figure 3), carlsbergite also occurs in troilite-daubréelite globules without "layered structure", where its micron-sized crystals may decorate the boundary between globule and host kamacite [49]. The phase relationships in the sulfide associations indicate that uakitite is one of the early minerals (Figures 5 and 6 ) and crystallized under temperature higher than that for troilite-daubréelite solid decay $\left(>1000^{\circ} \mathrm{C}\right)$.

We were unable to obtain physical and optical properties of uakitite due to the very small sizes of the grains. So, in most cases, we have to refer to data for synthetic VN. It has a yellow color, white streak and metallic luster. The mineral is transparent, non-fluorescent and brittle. No cleavage and parting are observed. The hardness for synthetic $\mathrm{VN}$ is $\approx 9-10$ (Mohs), microhardness: VHN load: 0.5-0.98 mN; range: $6.0-11.8 \mathrm{GPa}[33,46,47]$. The density $\left(6.128 \mathrm{~g} / \mathrm{cm}^{3}\right)$ for uakitite was calculated from unit-cell dimensions and results of EDS analyses. Under reflected light, uakitite is light gray with a pinky tint and does not show any internal reflections. Optical property data (transmitted light) for synthetic $\mathrm{VN}($ at $0.5876 \mu \mathrm{m})$ are: refractive index $n=2.3031, N_{\mathrm{g}}=1.4501$, reflectance $R=0.43817$ [31]. Uakitite is not soluble in $\mathrm{H}_{2} \mathrm{O}$ and weakly concentrated in $\mathrm{HCl}, \mathrm{HNO}_{3}$ and $\mathrm{H}_{2} \mathrm{SO}_{4}$. On BSE images, it resembles magnetite and daubréelite.
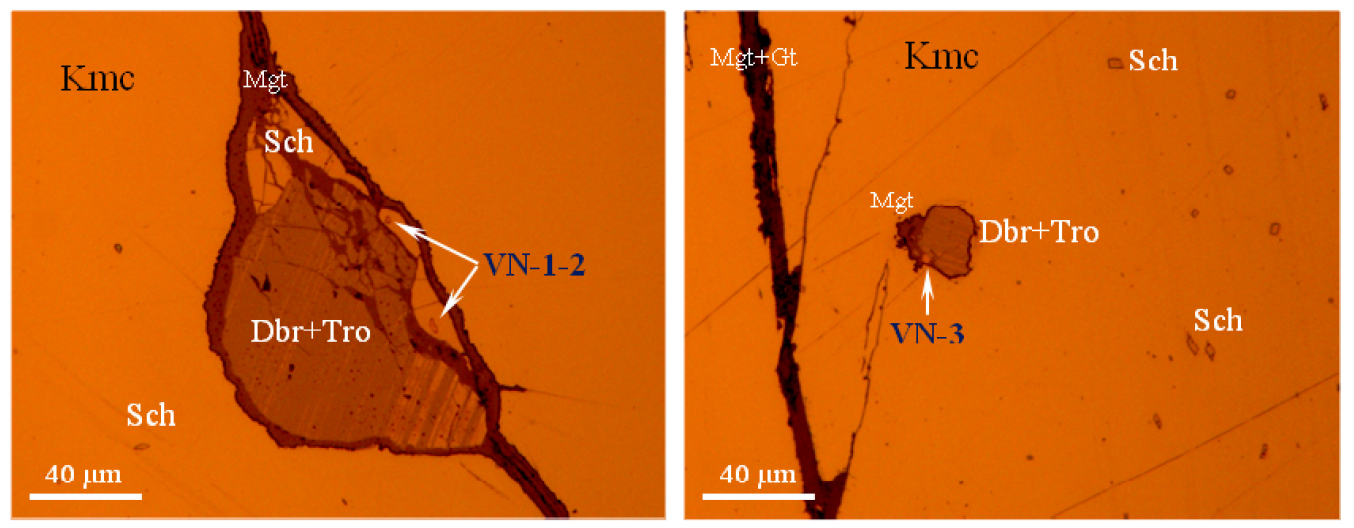

Figure 4. Uakitite in troilite + daubréelite \pm schreibersite globules in Fe-Ni-metal (kamacite), Uakit meteorite (IIAB), images in reflected light. Symbols: VN-1-VN-3-uakitite; Dbr-daubréelite; Tro—-troilite; Sch—schreibersite; Mgt—magnetite; Gt—goethite; Kmc—kamacite. 

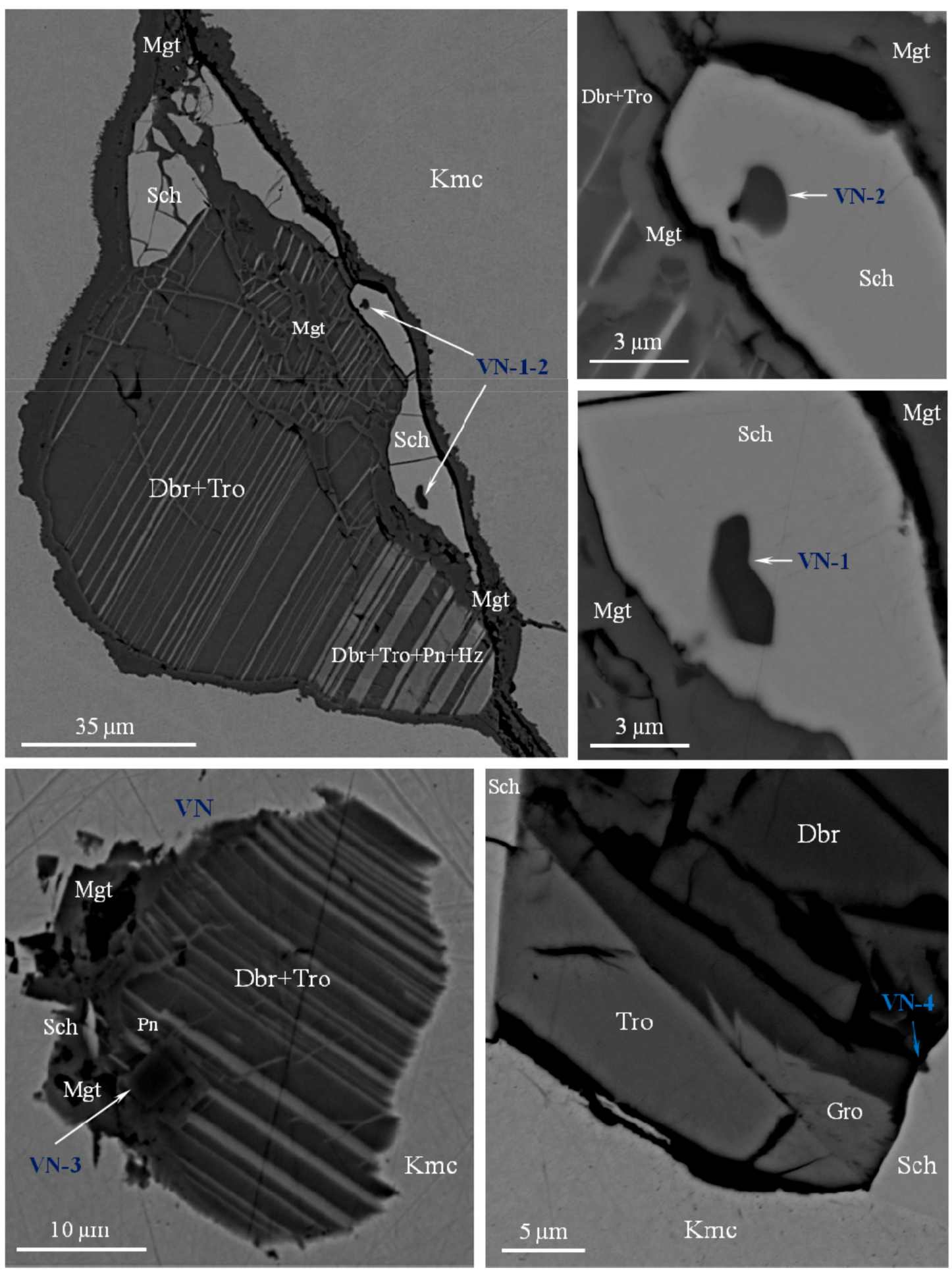

Figure 5. Uakitite in troilite-daubréelite \pm schreibersite globules in Fe-Ni-metal (kamacite), Uakit meteorite (IIAB), BSE images. Symbols: VN-1-VN-4-uakitite (see also Figure 4); Dbr-daubréelite; Tro—troilite; Sch—schreibersite; Mgt—magnetite; Kmc—kamacite, Pn—pentlandite; $\mathrm{Hz}$-heazlewoodite; Gro-grokhovkyite $\mathrm{CuCrS}_{2}$. 

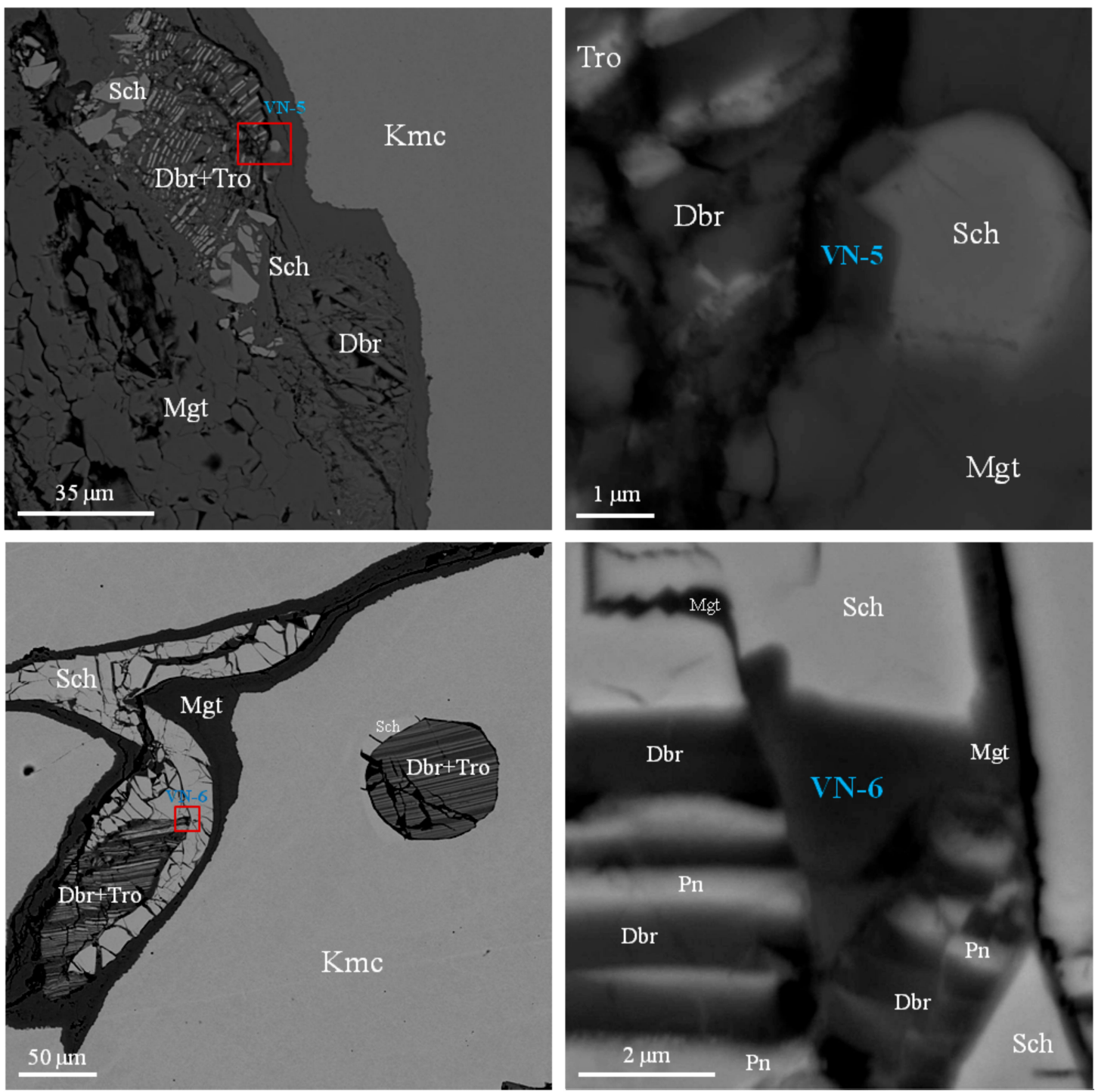

Figure 6. Uakitite in resorbed troilite-daubréelite-schreibersite globules from fissures filled with magnetite, Uakit meteorite (IIAB), BSE images. Symbols: VN-5, VN-6-uakitite; Dbr-daubréelite; Tro-troilite; Sch—schreibersite; Mgt—magnetite; Kmc—-kamacite.

\section{Chemical Composition of Uakitite}

The presence of elevated $\mathrm{Cr}$ and $\mathrm{Fe}$ and absence of $\mathrm{Ti}$ are characteristic features of uakitite. Its empirical formula ( $n=54$ ) based on two ions is $\mathrm{V}_{0.91} \mathrm{Cr}_{0.07} \mathrm{Fe}_{0.02} \mathrm{~N}_{1.00}$ (Table 2). In general, the variations in all components are negligible for individual uakitite grains. It is supported by elemental maps for some grains (Figure 8). The ideal formula for uakitite is VN, which requires V 78.43, N 21.57 and total 100.00 wt. \% (Table 2). Uakitite is structurally related to carlsbergite CrN and osbornite TiN [1,3,7-10,18]. The essential impurity of chromium incorporates in uakitite according to the scheme $\mathrm{V}^{3+} \rightarrow \mathrm{Cr}^{3+}$, up to 7 mol. \% of the carlsbergite end-member (Table 2, Figure 9). The isomorphic scheme for insignificant Fe (1.2-2.1 wt. \%) is unclear. Two variants are possible: $\mathrm{V}^{3+} \rightarrow \mathrm{Fe}^{3+}$ and $2 \mathrm{~V}^{3+} \rightarrow \mathrm{V}^{4+}+\mathrm{Fe}^{2+}$ (Figure 9). In contrast to uakitite, the concentration of $\mathrm{V}$ in carlsbergite is less than $0.2 \mathrm{wt}$. \%; Fe is up to $4.5 \mathrm{wt}$. \%; Ti was not detected (Table 2, Figure 9). In general, conditions for accumulation of $\mathrm{V}$ as $\mathrm{VN}$ are not yet clear. Bulk compositions of the Uakit meteorite and kamacite (ICP-MS and LA-ICP-MS) indicate very low vanadium concentrations of 0.04-0.52 ppm [25]. 

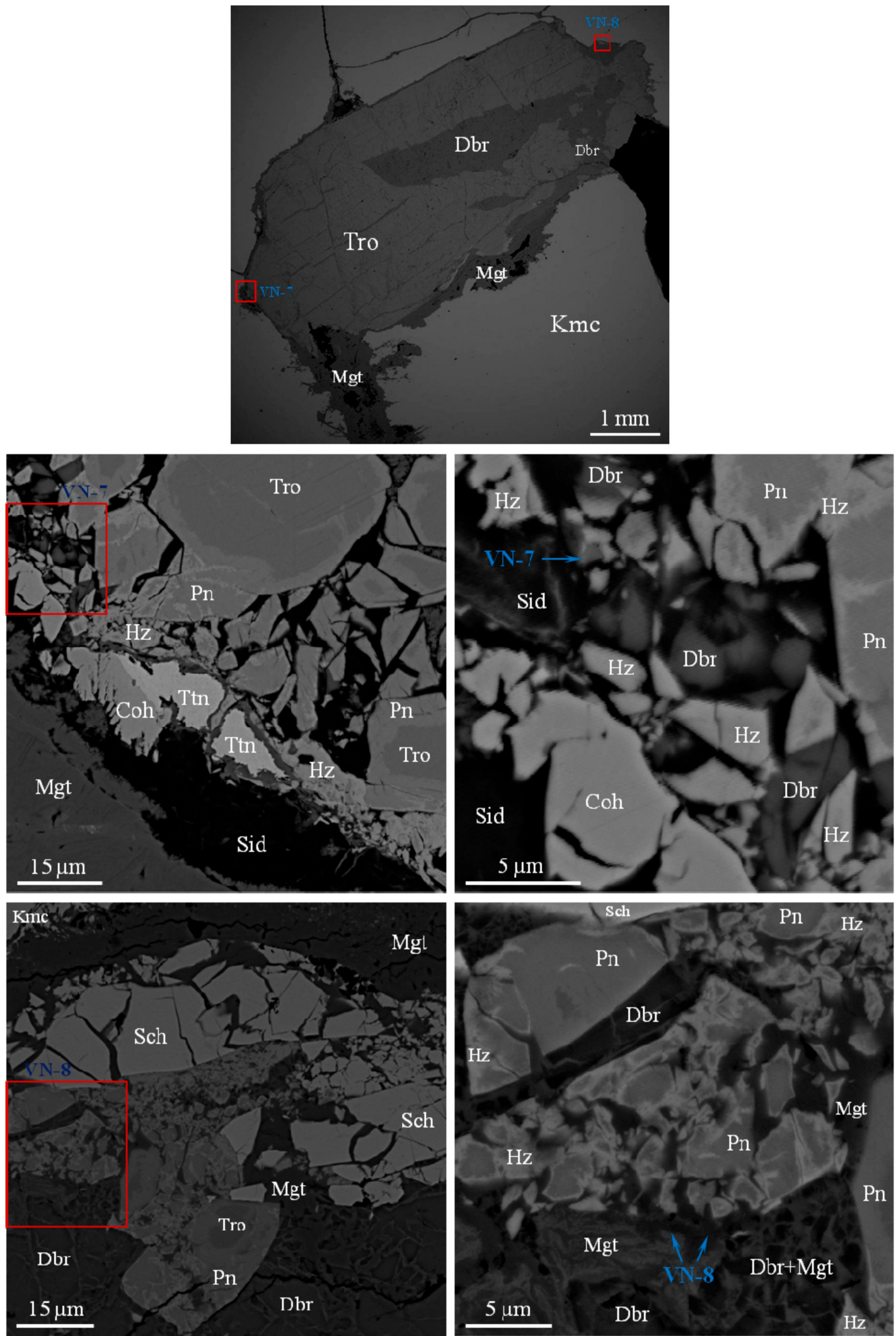

Figure 7. Uakitite in a large troilite-daubréelite nodule, Uakit meteorite (IIAB), BSE images. Symbols: VN-7, VN-8—uakitite; Dbr-daubréelite; Tro-troilite; Sch—schreibersite; Mgt—magnetite; Kmc—kamacite; $\mathrm{Pn} —$ pentlandite; Hz—heazlewoodite; Coh—cohenite; Ttn—tetrataenite; Sid—siderite. 

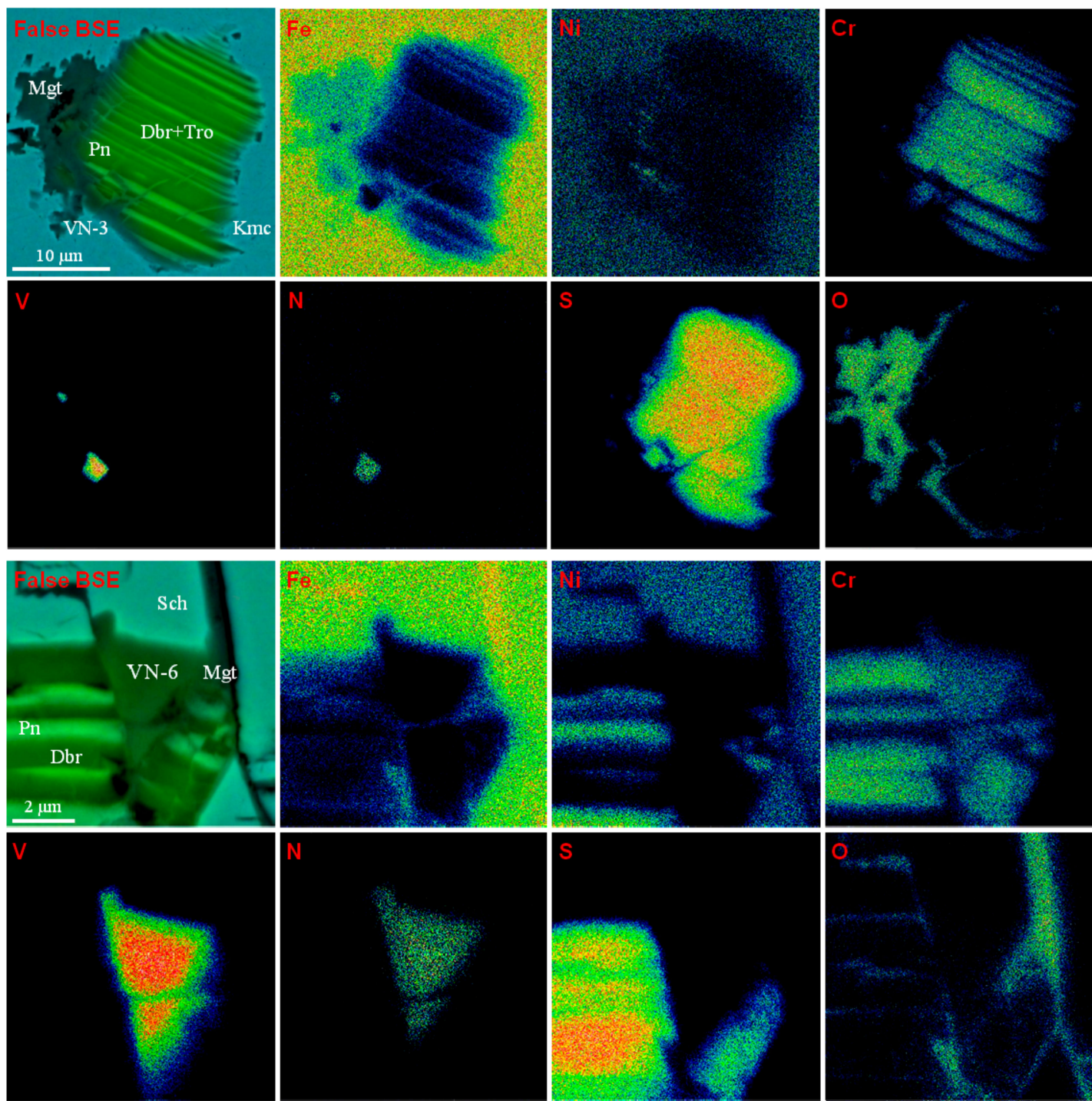

Figure 8. Elemental maps for troilite-daubréelite globules with uakitite. Symbols: VN-3, VN-6-uakitite (see Figures 5 and 6); Mgt-magnetite; Dbr+Tro—daubréelite+troilite; Kmc-kamacite; Sch-schreibersite; Pn-pentlandite.

Table 2. Chemical composition (EDS, wt. \%) of uakitite in comparison with ideal compositions and carlsbergite from the Uakit meteorite.

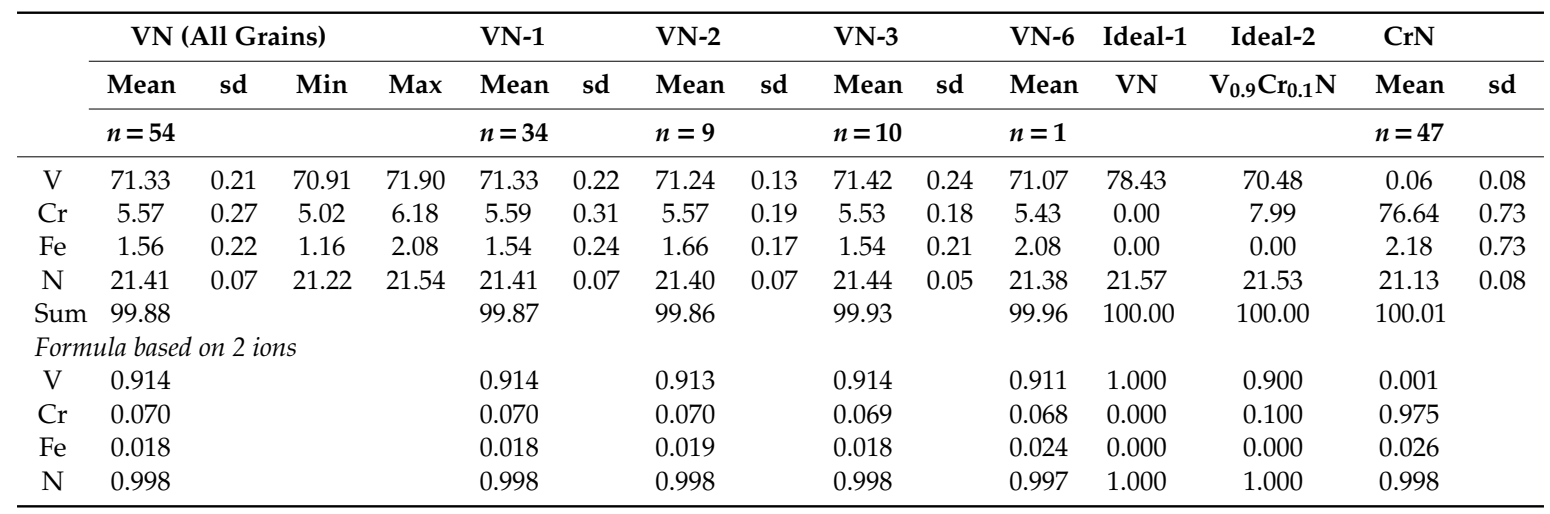

VN-1-VN-8-individual uakitite grains (see Figures 5, 6 and 8); $\mathrm{CrN}-$ carlsbergite. Ti is below detection limit $\left(<0.005\right.$ wt. \%). sd—standard deviation; Ideal-1-VN and Ideal-2- $\mathrm{V}_{0.9} \mathrm{Cr}_{0.1} \mathrm{~N}$. 

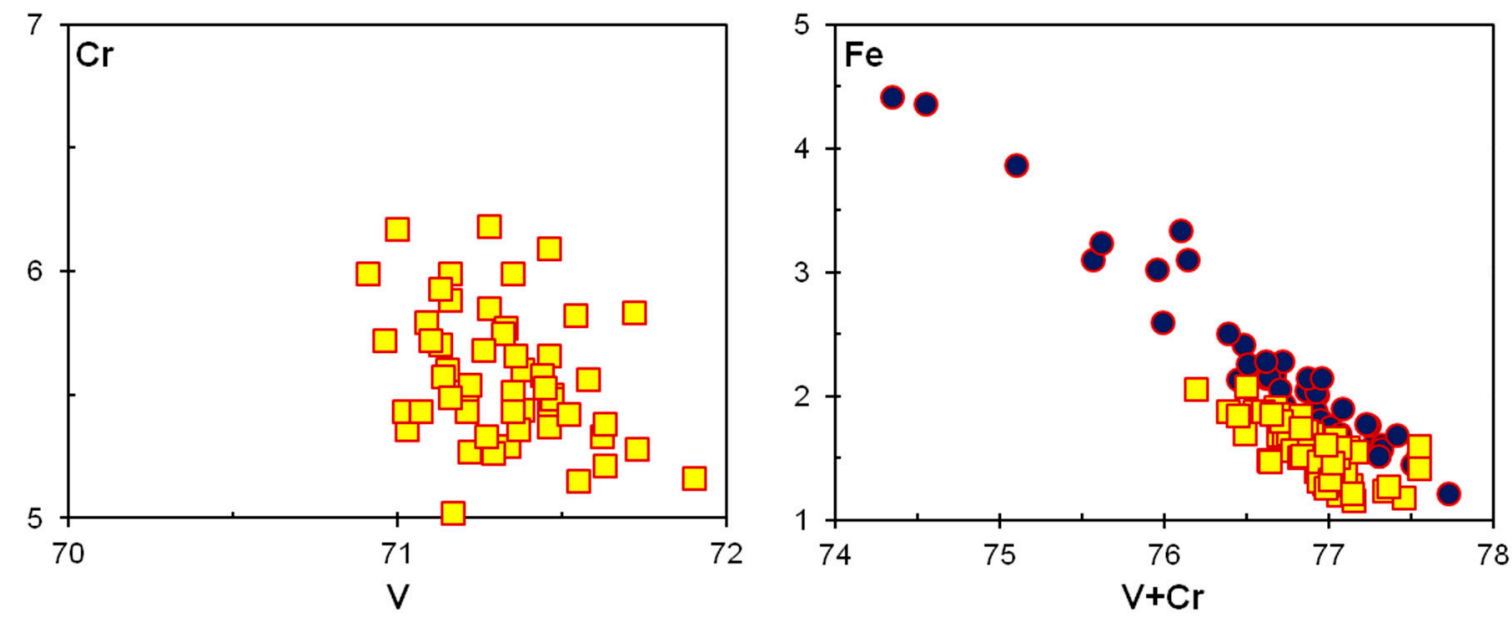

Figure 9. Chemical variations (in wt. \%) for uakitite and carlsbergite from the Uakit meteorite. Symbols: squares-uakitite; circles—carlsbergite.

\section{Crystal Structural Data for Uakitite}

It was difficult to obtain single-crystal and X-ray powder diffraction data for uakitite because of its very small crystal size $(<5 \mu \mathrm{m})$, and its mineral structure was resolved by EBSD method. Before considering the structure of uakitite, it is important to consider the data for the V-N system and the structure of the synthetic VN phase.

\subsection{System $V-N$}

Three stable solid phases are known in the system V-N: V, $\mathrm{V}_{2} \mathrm{~N}$ and $\mathrm{VN}$ [51-61]. Cubic $\mathrm{VN}_{1-\mathrm{x}}$ and hexagonal $\mathrm{V}_{2} \mathrm{~N}_{1-\mathrm{x}}$ are dominant solids in a very broad temperature range (Figure 10) according to [59,60]. Compound $\mathrm{VN}$ (or $\mathrm{VN}_{1-\mathrm{x}}$ or $\delta-\mathrm{VN}$ ) was firstly synthesized in the 1920s [29]. It is cubic (NaCl-type structure, $F m-3 m, a \approx 4.135 \AA, Z=4$ ): at high temperature (near melting point, $2050-2119{ }^{\circ} \mathrm{C}$ ), its composition is shifted to $\mathrm{VN}_{0.7-0.8}$, whereas at room temperature it is close to stoichiometric $\mathrm{VN}$. At temperatures below $230 \mathrm{~K}$, it transforms into a tetragonal, noncentrosymmetric low-temperature modification $(P-42 m, a=4.1314(3) \AA, c=4.1198(3) \AA$ at $45 \mathrm{~K})$ [62-64]. The melting point of cubic $\mathrm{VN}$ is increased up to $2800{ }^{\circ} \mathrm{C}$ at pressure $10 \mathrm{MPa}$ [58].

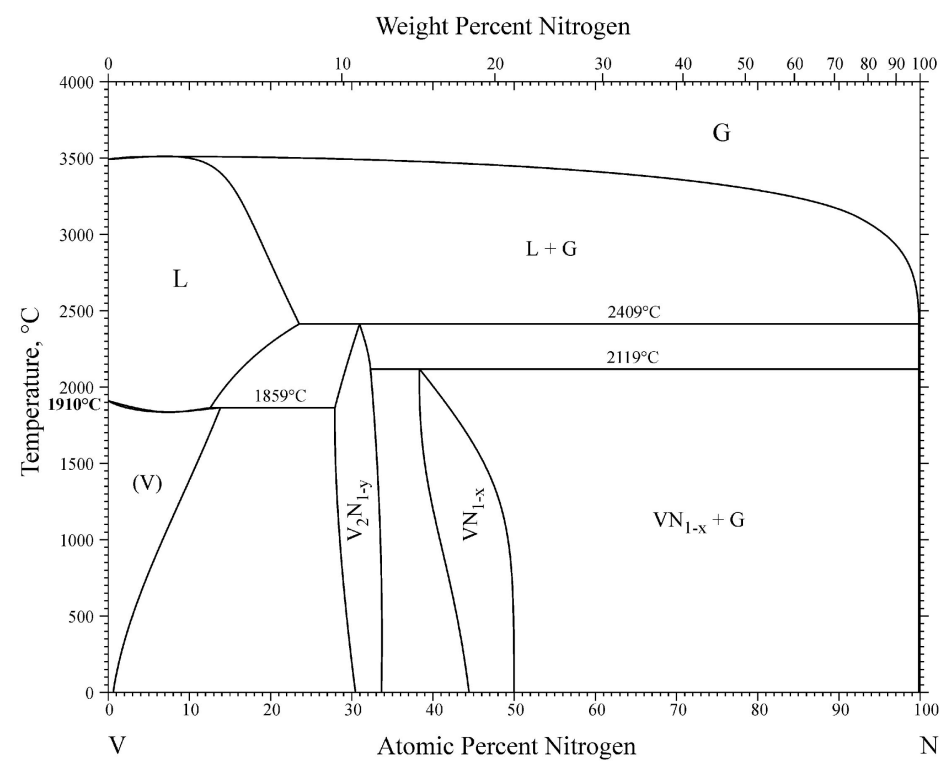

Figure 10. The phase diagram V-N at 1 atm $[59,60]$. 


\subsection{Crystal Structure for Synthetic VN}

In general, the crystal structure and properties of well-known synthetic VN (or $\delta$-VN) have been studied in detail $[29,30,40,42,44,51,62,64-82]$. It is a cubic NaCl-type structure (Fm-3m, $a \approx 4.135 \AA$, $\mathrm{Z}=4)$. The $\delta-\mathrm{VN}$ is isostructural with other transition metal nitrides $(\mathrm{CrN}, \mathrm{TiN}, \mathrm{ZrN}, \mathrm{NbN}$, etc.). The crystal structure of synthetic VN is shown in Figure 11.

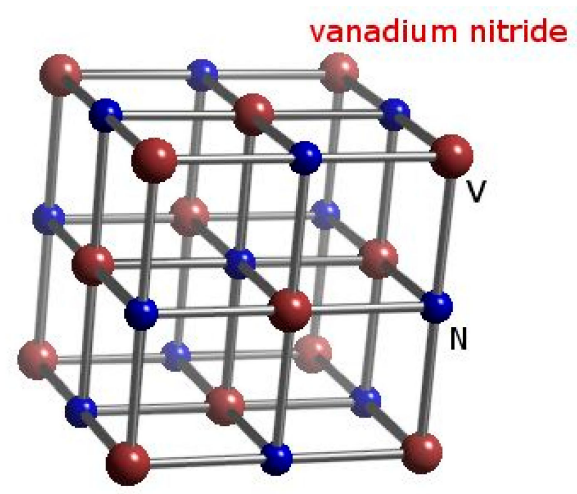

Figure 11. The crystal structure of synthetic VN [62].

\subsection{EBSD Data for Uakitite}

Single-crystal X-ray studies could not be carried out because of the small crystal size of uakitite. Structural data were obtained using the EBSD technique (Figure 12) and fitted to the following structural model of synthetic VN (space group Fm-3m (225); $a=4.1328(3) \AA ; V=70.588(9) \AA^{3} ; Z=4$ ) [62]. The EBSD patterns for three uakitite crystals were obtained at working distances of $15-20 \mathrm{~mm}$. Fitting of the EBSD patterns for a VN model with the cell parameters given below resulted in the parameter $\mathrm{MAD}=0.14-0.37^{\circ}$ (best-good fit). EBSD studies showed full structural identity between uakitite and its synthetic analog $\mathrm{VN}$ ( $\mathrm{NaCl}$-type). Uakitite is structurally related to the osbornite group which also includes carlsbergite $\mathrm{CrN}$ and osbornite TiN [1,3,7-10,18].

\subsection{Diffraction Data for Uakitite}

Because uakitite occurs only in small concentrations, X-ray powder diffraction data were not collected. The theoretical powder diffraction pattern was calculated using the structural data of the synthetic analog [62] and the empirical formula of uakitite (Table 2). Data are given in Table 3. Calculated structure data for uakitite are presented in Supplementary Materials (Cif file).

Table 3. Calculated powder diffraction data for uakitite.

\begin{tabular}{ccccc}
\hline$h$ & $k$ & $l$ & $d_{\text {calc }} \AA$ & $I_{\text {rel }}$ \\
\hline $\mathbf{1}$ & $\mathbf{1}$ & $\mathbf{1}$ & $\mathbf{2 . 3 8 6}$ & $\mathbf{7 1 . 2 2}$ \\
$\mathbf{2}$ & $\mathbf{0}$ & $\mathbf{0}$ & $\mathbf{2 . 0 6 6}$ & $\mathbf{1 0 0 . 0 0}$ \\
$\mathbf{2}$ & $\mathbf{2}$ & $\mathbf{0}$ & $\mathbf{1 . 4 6 1}$ & $\mathbf{6 1 . 1 5}$ \\
$\mathbf{3}$ & $\mathbf{1}$ & $\mathbf{1}$ & $\mathbf{1 . 2 4 6}$ & $\mathbf{2 9 . 1 2}$ \\
$\mathbf{2}$ & $\mathbf{2}$ & $\mathbf{2}$ & $\mathbf{1 . 1 9 3}$ & $\mathbf{1 8 . 9 2}$ \\
4 & 0 & 0 & 1.033 & 8.03 \\
$\mathbf{3}$ & $\mathbf{3}$ & $\mathbf{1}$ & $\mathbf{0 . 9 4 8}$ & $\mathbf{1 0 . 1 6}$ \\
$\mathbf{4}$ & $\mathbf{2}$ & $\mathbf{0}$ & $\mathbf{0 . 9 2 4}$ & $\mathbf{2 0 . 5 5}$ \\
$\mathbf{4}$ & $\mathbf{2}$ & $\mathbf{2}$ & $\mathbf{0 . 8 4 4}$ & $\mathbf{1 4 . 2 9}$ \\
5 & 1 & 1 & 0.795 & 4.99 \\
3 & 3 & 3 & 0.795 & 1.66 \\
4 & 4 & 0 & 0.731 & 4.08 \\
\hline
\end{tabular}

MoK $\alpha 1=0.70932 \AA$, Bregg-Brentano geometry, fixed slit, no anomalous dispersion, $I>1$; data were calculated using PowderCell 2.4 [83]. The strongest diffraction lines are given in bold. 

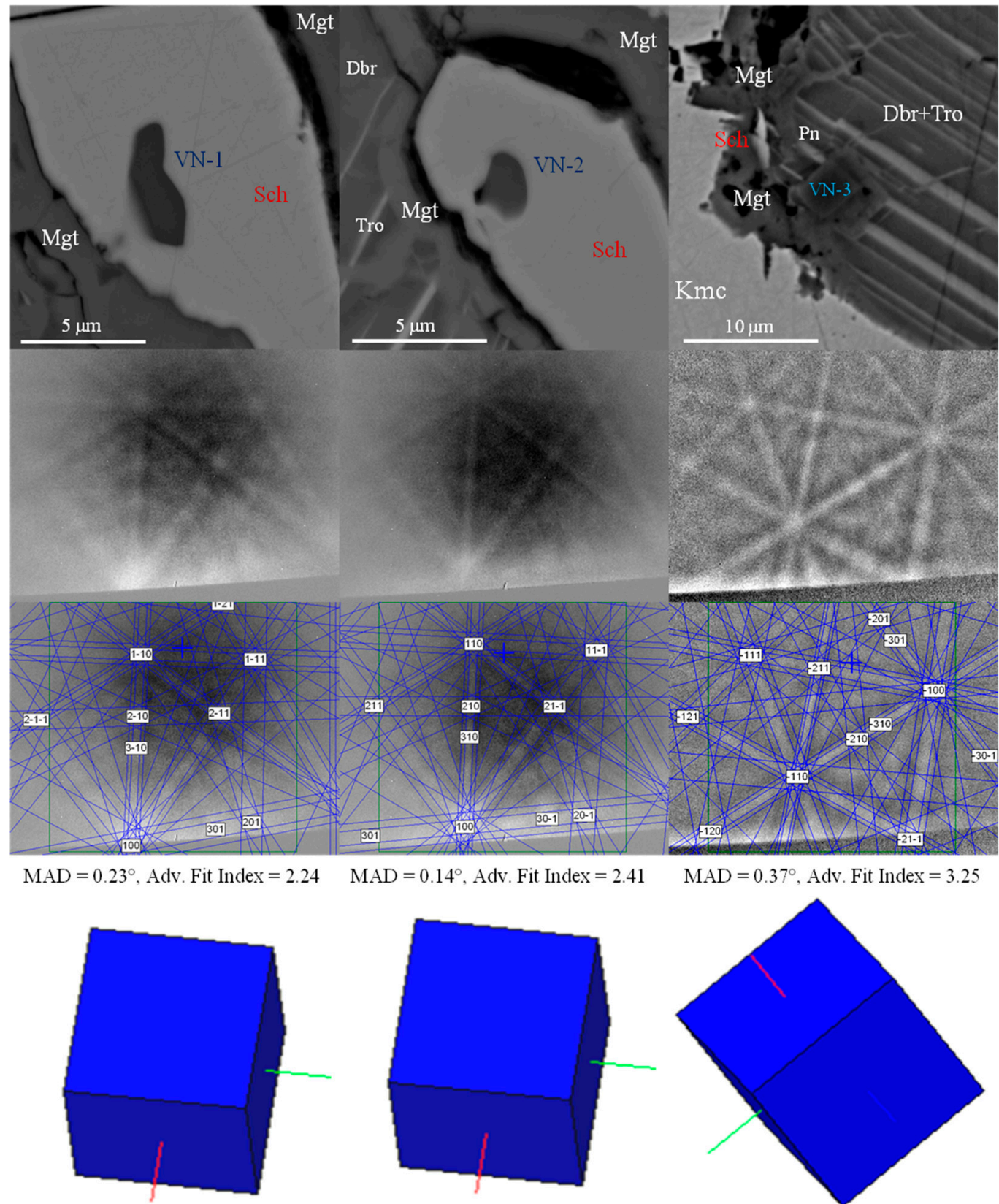

Figure 12. Electron backscattered diffraction (EBSD) patterns, the Kikuchi patterns and orientation for three grains of uakitite (detector distance: 15-20 mm). Symbols: VN-1-VN-3-uakitite (see Figure 5); Mgt—magnetite; Sch—schreibersite; Pn—pentlandite; Dbr + Tro—daubréelite + troilite; MAD—mean angular deviation.

\section{Discussion and Concluding Remarks}

The detailed mineralogical and petrographic studies for the Uakit iron meteorite gave a possibility to describe the chemical composition and some structural affinities for a new mineral, uakitite VN, which belongs to the osbornite group. Phase relations indicate that uakitite is one of the early minerals in the troilite-daubréelite associations. These sulfide associations in the Uakit meteorite seemed form due to high-temperature $\left(>1000^{\circ} \mathrm{C}\right)$ separation of Fe-Cr-rich sulfide liquid from Fe-metal melt. We do not exclude that crystallization of uakitite was under high temperature $\left(\approx 1000{ }^{\circ} \mathrm{C}\right)$ from the sulfide melt, but was not below $650 \pm 50{ }^{\circ} \mathrm{C}$ according to the system Cr-Fe-S [84]. In general, conditions for high accumulation of $\mathrm{V}$ as $\mathrm{VN}$ are not yet clear. Bulk compositions of whole meteorite and 
kamacite (ICP-MS and LA-ICP-MS) indicate very low vanadium concentrations 0.04-0.52 ppm [25]. Probably sulfide-metal liquid immiscibility is the main factor for the partitioning of chalcophile $\mathrm{V}$ (and also $\mathrm{Cr}$ ) in sulfide melt.

The discovery of uakitite in conjunction with occurrences for other extraterrestrial nitrides indicates the very interesting regularity in their appearance [1-20]. Carlsbergite, uakitite and roaldite are characteristic minerals of iron meteorites, whereas osbornite, nierite and sinoite occur solely in stone meteorites (carbonaceous chondrites, enstatite chondrites and achondrites). Possibly, it is also related to the chalcophile character of elements.

Some rare and exotic minerals occur as very minute grains (size: $<1-20 \mu \mathrm{m}$ and smaller). It creates a lot of problems in their identification and detailed description; especially in regards to new mineral species (composition, unit-cell data and crystal structure). However, modern analytical methods permit the study of such small objects. In addition to the classic analytical methods, the application of the TEM, EBSD and other techniques allow for improved studies of micron-sized minerals. In the last decades, these technologies are successfully used for detailed identification of new minerals in both meteorites and terrestrial rocks, especially when their synthetic analogs are known (for example $[26,48,85-89]$ and many other works).

Supplementary Materials: The following are available online at http://www.mdpi.com/2075-163X/10/2/150/s1, Cif file: uakitite.

Author Contributions: V.V.S. and G.S.R. wrote the paper. V.V.S. performed the mineralogical description and measurements of chemical composition of uakitite and related minerals (EMPA). G.S.R., I.A.I. and E.A.K. provided preliminary SEM studies. G.A.Y., V.I.G., E.A.K., N.S.K., I.A.I. and Y.V.S. provided EBSD, SEM and structural studies. All authors have read and agreed to the published version of the manuscript.

Funding: The investigations were partly supported by RFBR (grant 17-05-00129) and the State assignment project (IGM SD 0330-2016-0005). This work was also supported by the Initiative Project of Ministry of Science and Higher Education of the Russian Federation and by Act 211 of the Government of the Russian Federation, agreement no. 02.A03.21.0006.

Acknowledgments: The authors would like to thank E.N. Nigmatulina and M.V. Khlestov (IGM) for technical assistance at EMPA and SEM studies. We also would like to thank Adam Abersteiner (University of Tasmania) for assistance in the English correcting of the last version of the manuscript. We are highly appreciative of the valuable comments and suggestions of two anonymous reviewers.

Conflicts of Interest: The authors declare no conflicts of interest.

\section{References}

1. Bannister, F.A. Osbornite, meteoritic titanium nitride. Mineral. Mag. 1941, 26, 36-44. [CrossRef]

2. Andersen, C.A.; Keil, K.; Mason, B. Silicon oxynitride: A meteoritic mineral. Science 1964, 146, 256-257. [CrossRef] [PubMed]

3. Buchwald, V.F.; Scott, E.R.D. First nitride (CrN) in iron meteorites. Nat. Phys. Sci. 1971, 233, 113-114. [CrossRef]

4. Ramdohr, P. The Opaque Minerals in Stony Meteorites; Elsevier Publishing Company: Amsterdam, The Netherlands; London, UK; New York, NY, USA, 1973; 245p.

5. Buchwald, V.F. Handbook of Iron Meteorites; University California Press: Berkeley, CA, USA, 1975.

6. Nielsen, H.P.; Buchwald, V.F. Roaldite, a new nitride in iron meteorites. Proc. Lunar Planet. Sci. Conf. 1981, $12,1343-1348$.

7. Axon, H.J.; Kinder, J.; Haworth, C.W.; Horsfield, J.W. Carlsbergite, CrN, in troilite, FeS, of the Sikhote Alin meteoritic iron. Mineral. Mag. 1981, 44, 107-109. [CrossRef]

8. Khodakovsky, I.L.; Petaev, M.I. Thermodynamic properties and formation conditions for osbornite, sinoite and carlsbergite in meteorites. Geokhimiya 1981, 19, 329-340. (In Russian)

9. Nolze, G.; Wagner, G.; Saliwan Neumann, R.; Skála, R.; Geist, V. Orientation relationships of carlsbergite in schreibersite and kamacite in the north Chile iron meteorite. Mineral. Mag. 2006, 70, 373-382. [CrossRef]

10. Casanova, I. Osbornite and the distribution of titanium in enstatite meteorites. Meteoritics 1992, 27, 208-209.

11. Russell, S.S.; Lee, M.R.; Arden, J.W.; Pillinger, C.T. The isotopic composition and origins of silicon nitride in ordinary and enstatite chondrites. Meteoritics 1995, 30, 399-404. [CrossRef] 
12. Hoppe, P.; Geiss, J.; El Goresy, A. Nitrogen isotopes in sinoite grains of the Yilmia enstatite chondrite. Meteoritics 1989, 24, 278-298.

13. Weber, D.; Zinner, E.K.; Bishoff, A. An ion microprobe study of an osbornite-bearing inclusion from ALH-85085. Meteoritics 1994, 29, 547-548.

14. Rubin, A.E. Sinoite $\left(\mathrm{Si}_{2} \mathrm{~N}_{2} \mathrm{O}\right)$ : Crystallization from EL chondrite impact melts. Am. Mineral. 1997, 82, 1001-1006. [CrossRef]

15. Lee, M.R.; Russell, S.S.; Arden, J.W.; Pillinger, C.T. Nierite $\left(\mathrm{Si}_{3} \mathrm{~N}_{4}\right)$, a new mineral from ordinary and enstatite chondrites. Meteoritics 1995, 30, 387-398. [CrossRef]

16. Alexander, C.M.O.; Barber, D.J.; Hutchison, R.H. The microstructure of Semarkona and Bishunpur. Geochim. Cosmochim. Acta 1989, 53, 3045-3057. [CrossRef]

17. Alexander, C.M.O.D.; Swan, P.; Prombo, C.A. Occurrence and implications of silicon nitride in enstatite chondrites. Meteoritics 1994, 29, 79-85. [CrossRef]

18. Grokhovsky, V.I. Osbornite in CB/CH-like Carbonaceous Chondrite Isheyevo. Meteorit. Planet. Sci. 2006, 41 (Suppl. 8), A68.

19. Rubin, A.E.; Ma, C. Meteoritic minerals and their origins. Chem. Erde 2017, 77, 325-385. [CrossRef]

20. McCoy, T.J.; Keil, K.; Bogard, D.D.; Garrison, D.H.; Casanova, I.; Lindstrom, M.M.; Brearley, A.J.; Kehm, K.; Nichols, R.H.; Hohenberg, C.M. Origin and history of impact-melt rocks of enstatite chondrite parentage. Geochim. Cosmochim. Acta 1995, 59, 161-175. [CrossRef]

21. Silvestri, O. Das Vorkommen des Stickstoffeisens unter den Fumarolen-Producten des Aetna und Künstliche Darstellung dieser Verbindung. Ann. Phys. Chem. 1876, 157, 165-172. (In German) [CrossRef]

22. Charles, P.; Berman, H.; Frondel, C. The System of Mineralogy of James Dwight Dana and Edward Salisbury Dana. Yale University 1837-1892, Seventh edition. Science 1944, 1, 126.

23. Russo, M. I Minerali di Formazione Fumarolica della Grande Eruzione Vesuviana del 1906; Open File Report; Istituto Nazionale di Geofisica e Vulcanologia, sezione Napoli-Osservatorio Vesuviano: Napoli, Italy, 2006; Volume 6, 39p. (In Italian)

24. Lastochkin, E.I.; Ripp, G.S.; Izbrodin, I.A.; Khromova, E.A.; Sharygin, V.V. Mineral composition of meteorite Uakit (Republic of Buryatia). In Proceedings of the IV Russian Young Scientists Conference; GIN SB RAS, Ulan-Ude, Russia, 30 April-1 June 2017; pp. 146-148. (In Russian).

25. Ripp, G.S.; Sharygin, V.V.; Izbrodin, I.A.; Ragozin, A.L.; Khromova, E.A. Mineralogy and geochemistry of iron meteorite Uakit (IIAB), Buryatia. In Proceedings of the 200th Anniversary Meeting of the Russian Mineralogical Society, Saint-Petersburg, Russia, 10-13 October 2017; Volume 2, pp. 311-313. (In Russian).

26. Sharygin, V.V.; Ripp, G.S.; Yakovlev, G.A.; Seryotkin, Y.V.; Karmanov, N.S.; Izbrodin, I.A.; Grokhovsky, V.I.; Khromova, E.A. Uakitite, IMA 2018-003. CNMNC Newsletter No. 43, June 2018, page 781. Mineral. Mag. 2018, 82, 779-785.

27. Sharygin, V.V.; Ripp, G.S.; Yakovlev, G.A.; Seryotkin, Y.V.; Karmanov, N.S.; Izbrodin, I.A.; Grokhovsky, V.I.; Khromova, E.A. Uakitite VN, a new nitride in iron meteorites. Meteorit. Planet. Sci. 2018, 53, 6052.

28. Sharygin, V.V.; Ripp, G.S.; Yakovlev, G.A.; Seryotkin, Y.V.; Karmanov, N.S. New mineral species in iron meteorite Uakit (IIAB), Buryatia. In Abstracts of International Conference dedicated to the 110th anniversary of Academician V.S. Sobolev "The Problems of Magmatic and Metamorphic Petrology, Geodynamics and Genesis Of Diamonds"; IGM SD RAS, Publishing House of SB RAS: Novosibirsk, Russia, 2018; p. 167.

29. Becker, K.; Ebert, F. Die Kristallstruktur einiger binärer Carbide und Nitride. Z. Phys. 1925, 31, $268-272$. (In German) [CrossRef]

30. Pessall, N.; Gold, R.E.; Johansen, H.A. A study of superconductivity in interstitial compounds. J. Phys. Chem. Solids 1968, 29, 19-38. [CrossRef]

31. Pflüger, J.; Fink, J.; Weber, W.; Bohnen, K.P.; Crecelius, G. Dielectric properties of $\mathrm{TiC}_{\mathrm{x}}, \mathrm{TiN}_{\mathrm{x}}, \mathrm{VC}_{\mathrm{x}}, \mathrm{and} \mathrm{VN}_{\mathrm{x}}$ from 1.5 to $40 \mathrm{eV}$ determined by electron-energy-loss spectroscopy. Phys. Rev. B Condens. Matter 1984, 30, $1155-1163$.

32. Zhao, B.R.; Chen, L.; Luo, H.L.; Jack, M.D.; Mullin, D.P. Superconducting and normal-state properties of vanadium nitride. Phys. Rev. B Condens. Matter 1984, 29, 6198-6202. [CrossRef]

33. Lengauer, W.; Ettmayer, P. Physical and mechanical properties of cubic $\delta-\mathrm{VN}_{1-\mathrm{x}}$. J. Less Common Met. 1985, 109, 351-359. [CrossRef]

34. Yeh, C.L.; Chuang, H.C.; Liu, E.W.; Chang, Y.C. Effects of dilution and preheating on SHS of vanadium nitride. Ceram. Int. 2005, 31, 95-104. [CrossRef] 
35. Choi, D.; Blomgren, G.E.; Kumta, P.N. Fast and reversible surface redox reaction in nanocrystalline vanadium nitride supercapacitors. Adv. Mater. 2006, 18, 1178-1182. [CrossRef]

36. Muñoz Riofano, R.M.; Casteletti, L.; Nascente, P.A.P. Study of the wear behavior of ion nitrided steels with different vanadium contents. Surf. Coat. Tech. 2006, 200, 6101-6110. [CrossRef]

37. Glaser, A.; Surnev, S.; Netzer, F.P.; Fateh, N.; Fontalvo, G.A.; Mitterer, C. Oxidation of vanadium nitride and titanium nitride coatings. Surf. Sci. 2007, 601, 1153-1159. [CrossRef]

38. Huang, J.-W.; Peng, H.; Xia, G.-B. Microwave synthesis of vanadium nitride for industrial applications. Ironmak. Steelmak. 2009, 36, 110-114. [CrossRef]

39. Huang, T.; Mao, S.; Zhou, G.; Wen, Z.; Huang, X.; Cib, S.; Chen, J. Hydrothermal synthesis of vanadium nitride and modulation of its catalytic performance for oxygen reduction reaction. Nanoscale 2014, 6, 9608-9613. [CrossRef] [PubMed]

40. Qiu, Y.; Zhang, S.; Li, B.; Wang, Y.; Lee, J.-W.; Li, F.; Zhao, D. Improvement of tribological performance of CrN coating via multilayering with VN. Surf. Coat. Tech. 2013, 231, 357-363. [CrossRef]

41. Mishra, P.P.; Theerthagiri, J.; Panda, R.N. Mesoporous vanadium nitride synthesized by chemical routes. Adsorpt. Sci. Technol. 2014, 32, 465-474. [CrossRef]

42. Sen, U. Thermo-reactive diffusion vanadium nitride coatings on AISI 1020 steel. Key Eng. Mat. 2004, 264-268, 577-580. [CrossRef]

43. Gyger, F.; Bockstaller, P.; Gerthsen, D.; Feldmann, C. Liquid-crystalline phases with liquid ammonia: Synthesis of porous $\mathrm{Si}_{3} \mathrm{~N}_{4}, \mathrm{TiN}, \mathrm{VN}$, and $\mathrm{H}_{2}$-sorption of $\mathrm{Si}_{3} \mathrm{~N}_{4}$ and $\mathrm{Pd} @ \mathrm{Si}_{3} \mathrm{~N}_{4}$. Chem. Mater. 2016, 28, 7816-7824. [CrossRef]

44. Morel, A.; Borjon-Piron, Y.; Porto, R.L.; Brousse, T.; Bélangerc, D. Suitable conditions for the use of vanadium nitride as an electrode for electrochemical capacitor. J. Electrochem. Soc. 2016, 163, A1077-A1082. [CrossRef]

45. Han, J.; Zhang, Y.; Liu, T.; Huang, J.; Xue, N.; Hu, P. Preparation of vanadium nitride using a thermally processed precursor with coating structure. Metals 2017, 7, 360. [CrossRef]

46. Davies, K.E.; Gan, B.K.; McKenzie, D.R.; Bilek, M.M.M.; Taylor, M.B.; McCulloch, D.G.; Latella, B.A. Correlation between stress and hardness in pulsed cathodic arc deposited titanium/vanadium nitride alloys. J. Phys. Condens. Matter 2004, 16, 7947-7954. [CrossRef]

47. Wang, S.; Yu, X.; Zhang, J.; Wang, L.; Leinenweber, K.; He, D.; Zhao, Y. Synthesis, hardness, and electronic properties of stoichiometric VN and CrN. Cryst. Growth Des. 2016, 16, 351-358. [CrossRef]

48. Sharygin, V.V. Phase $\mathrm{CuCrS}_{2}$ in Uakit iron meteorite (IIAB), Buryatia, Russia: Preliminary data. In Spri. Proceed. in Earth, Environ. Sci., Book "Minerals: Structure, Properties, Methods of Investigation", 9th Geoscience Conference for Young Scientists, Ekaterinburg, Russia, February 5-8, 2018; Votyakov, S., Kiseleva, D., Grokhovsky, V., Shchapova, Y., Eds.; Springer International Publishing: Berlin/Heidelberg, Germany, 2020; pp. 229-236. [CrossRef]

49. Sharygin, V.V.; Yakovlev, G.A.; Seryotkin, Y.V.; Karmanov, N.S.; Novoselov, K.A.; Karabanalov, M.S. Grokhovskyite, IMA 2019-065. CNMNC Newsletter No. 52; December 2019, page 890. Mineral. Mag. 2019, 83, 887-893. [CrossRef]

50. Pouchou, I.L.; Pichoir, F. “PaP” (phi-rho-z) procedure for improved quantitative microanalysis. In Microbeam Analysis; Armstrong, I.T., Ed.; San Francisco Press: San Francisco, CA, USA, 1985; pp. 104-106.

51. Arbuzov, M.P.; Khaenko, B.V.; Frenkel, O.A. X-ray diffraction investigation of the phases in the system V-N. Neorg. Mater. 1975, 11, 196-200. (In Russian)

52. Khaenko, B.V. X-ray examination of phase equilibria in V-N system. Dopovidi Akademii Nauk Ukr. RSR Seriya A Fiz. Mat. Tekhnichni Nauk. 1977, 39, 275-279. (In Ukrainian)

53. Onozuka, T. Vacancy ordering in $\mathrm{VN}_{1-\mathrm{x}}$. J. Appl. Crystallogr. 1978, 11, 132-136. [CrossRef]

54. Onozuka, $\mathrm{T}$. Nitrogen ordering in $\mathrm{V}_{9} \mathrm{~N}_{4}$ and $\mathrm{V}_{32} \mathrm{~N}_{16}$ studied by neutron and electron diffraction. T. Jpn. I. Met. 1982, 23, 315-319. [CrossRef]

55. Carlson, O.N.; Smith, J.F.; Nafziger, R.H. N-V (Nitrogen-Vanadium). In Binary Alloy Phase Diagrams, 2nd ed.; Massalski, T.B., Ed.; ASM International: Materials Park, OH, USA, 1990; Volume 3, pp. 2709-2712.

56. Ohtani, H.; Hillert, M. A thermodynamic assessment of the V-N system. Calphad 1991, 15, 11-24. [CrossRef]

57. Ohtani, H.; Hillert, M. A thermodynamic assessment of the Fe-N-V system. Calphad 1991, 15, 25-39. [CrossRef]

58. Okamoto, H. Comment on N-V (Nitrogen-Vanadium). J. Phase Equilib. 1994, 15, 454. [CrossRef]

59. Okamoto, H. N-V (Nitrogen-Vanadium). J. Phase Equilib. 2001, 22, 362. [CrossRef] 
60. Du, Y.; Schmid-Fetzer, R.; Ohtani, H. Phase Diagram V-N. Z. Metallkd. 1997, 88, 545-556.

61. Ravi, C.; Sahu, H.K.; Valsakumar, M.C.; van de Walle, A. Cluster expansion Monte Carlo study of phase stability of vanadium nitrides. Phys. Rev. B Condens. Matter 2010, 81, 104111. [CrossRef]

62. Kubel, F.; Lengauer, W.; Yvon, K.; Knorr, K.; Junod, A. Structural phase transition at 205 K in stoichiometric vanadium nitride. Phys. Rev. B Condens. Matter 1988, 38, 12908-12912. [CrossRef]

63. Ivashchenko, V.I.; Turchi, P.E.A. Phonon softening and the phase transition in VN. Phys. Rev. B Condens. Matter 2008, 78, 224113. [CrossRef]

64. Mei, A.B.; Hellman, O.; Wireklint, N.; Schlepütz, C.M.; Sangiovanni, D.G.; Alling, B.; Rockett, A.; Hultman, L.; Petrov, I.; Greene, J.E. Dynamic and structural stability of cubic vanadium nitride. Phys. Rev. B Condens. Matter 2015, 91, 054101. [CrossRef]

65. Duwez, P.E.; Odell, F. Phase Relationships in the Binary Systems of Nitrides and Carbides of Zirconium, Columbium, Titanium, and Vanadium. J. Electrochem. Soc. 1950, 97, 299-304. [CrossRef]

66. Schönberg, N. An X-ray investigation on ternary phases in the Ta-Me-N systems (Me = Ti, Cr, Mn, Fe, Co, Ni). Acta Chem. Scandinavica 1954, 8, 213-220. [CrossRef]

67. Nowotny, H.; Benesovsky, F.; Rudy, E. Hochschmelzende Systeme mit Hafniumkarbid und -nitrid. Monat. Chem. Verw. Tl. 1960, 91, 348-356. (In German) [CrossRef]

68. Brauer, G.; Schnell, W.D. Zur Kenntnis des Systems Vanadium-Stickstoff und des reinen Vanadiums. J. Less Common Met. 1964, 6, 326-332. (In German) [CrossRef]

69. Yen, C.M.; Toth, L.E.; Shy, Y.M.; Anderson, D.E.; Rosner, L.G. Superconducting $\mathrm{H}_{\mathrm{c}}-\mathrm{J}_{\mathrm{c}}$ and $\mathrm{T}_{\mathrm{c}}$ measurements in the Nb-Ti-N, Nb-Hf-N, and Nb-V-N ternary systems. J. Appl. Phys. 1967, 38, 2268-2271. [CrossRef]

70. Hosoya, S.; Yamagishi, T.; Tokonami, M. Study of electron state in vanadium nitride by intensity measurements of X-ray diffraction. J. Phys. Soc. Jpn. 1968, 24, 363-367. [CrossRef]

71. Spear, K.E.; Leitnaker, J.M. Equilibrium investigations of carbon-rich V(C,N) solutions. High Temp. Sci. 1969, 1, 401-411.

72. Kieffer, R.; Nowotny, H.; Ettmayer, P.; Dufek, G. Neue Untersuchungen über die Mischbarkeit von Elbergangsmetallnitriden und -karbiden. Met. (Berl.) (Met. (Heidelb.)) 1972, 26, 701-708. (In German)

73. Gatterer, J.; Dufek, G.; Ettmayer, P.; Kieffer, R. Das kubische Tantalmononitrid (B1-Typ) und seine Mischbarkeit mit den isotypen Übergangsmetall-nitriden und -carbiden. Monat. Chem. Verw. Tl. 1975, 106, 1137-1147. (In German) [CrossRef]

74. Eddine, M.N.; Bertaut, E.F.; Roubin, M.; Paris, J. Etude cristallographique de $\mathrm{Cr}_{1-\mathrm{x}} \mathrm{V}_{\mathrm{x}} \mathrm{N}$ a basse température. Acta Crystall. B Stru 1977, 33, 3010-3013. (In French) [CrossRef]

75. Ettmayer, P.; Schebesta, W.; Vendl, A.; Kieffer, R. Beitrag zur Kenntnis des Systems Vanadin-Chrom-Stickstoff. Monat. Chem. Verw. Tl. 1978, 109, 929-941. [CrossRef]

76. Yang, X.; Li, C.; Yang, B.; Wang, W.; Qian, Y. Thermal nitridation synthesis of MN (M = Ti, V and Cr) nanocrystals from metals and $\mathrm{NH}_{4} \mathrm{Cl}$. Mater. Res. Bull. 2004, 39, 957-962. [CrossRef]

77. Hasegawa, M.; Yagi, T. Systematic study of formation and crystal structure of 3d-transition metal nitrides synthesized in a supercritical nitrogen fluid under $10 \mathrm{GPa}$ and $1800 \mathrm{~K}$ using diamond anvill cell and YAG laser heating. J. Alloy Compd. 2005, 403, 131-142. [CrossRef]

78. Gajbhiye, N.S.; Ningthoujam, R.S. Low temperature synthesis, crystal structure and thermal stability studies of nanocrystalline VN particles. Mater. Res. Bull. 2006, 41, 1612-1621. [CrossRef]

79. Zhao, H.; Lei, M.; Chen, X.; Tang, W. Facile route to metal nitrides through melamine and metal oxides. J. Mater. Chem. 2006, 16, 4407-4412. [CrossRef]

80. Fokin, V.N.; Fokina, E.E.; Tarasov, B.P. Reaction of the intermetallide $\mathrm{ZrV}_{2}$ with ammonia. Russ. J. Inorg. Chem. 2012, 57, 21-23. [CrossRef]

81. Lei, L.; Yin, W.; Jiang, X.; Lin, S.; He, D. Synthetic route to metal nitrides: High-pressure solid-state metathesis reaction. Inorg. Chem. 2013, 52, 13356-13362. [CrossRef] [PubMed]

82. Saravanakannan, V.; Radhakrishnan, T. Influence of oxygen and titanium substitution on vanadium nitride nanostructures-ADFT study. Int. J. Chem. Tech. Res. 2014, 6, 5745-5750.

83. Kraus, W.; Nolze, G. POWDER CELL-A program for the representation and manipulation of crystal structures and calculation of the resulting X-ray powder patterns. J. Appl. Crystallogr. 1996, 29, 301-303. [CrossRef] 
84. El Goresy, A.; Kullerud, G. Phase Relations in the System Cr-Fe-S. In Meteorite Research: Proceedings of a Symposium on Meteorite Research Held in Vienna, Austria, 7-13 August 1968; Millman, P.M., Ed.; D. Reidel Publishing Co.: Dordrecht, The Netherlands, 1969; pp. 638-656.

85. Ma, C.; Beckett, J.R.; Rossman, G.R. Allendeite $\left(\mathrm{Sc}_{4} \mathrm{Zr}_{3} \mathrm{O}_{12}\right)$ and hexamolybdenum (Mo,Ru,Fe), two new minerals from an ultrarefractory inclusion from the Allende meteorite. Am. Mineral. 2014, 99, 654-666. [CrossRef]

86. Ma, C.; Krot, A.N. Hutcheonite, $\mathrm{Ca}_{3} \mathrm{Ti}_{2}\left(\mathrm{SiAl}_{2}\right) \mathrm{O}_{12}$, a new garnet mineral from the Allende meteorite: An alteration phase in a Ca-Al-rich inclusion. Am. Mineral. 2014, 99, 667-670. [CrossRef]

87. Ma, C.; Beckett, J.R. Nuwaite $\left(\mathrm{Ni}_{6} \mathrm{GeS}_{2}\right)$ and butianite $\left(\mathrm{Ni}_{6} \mathrm{SnS}_{2}\right)$, two new minerals from the Allende meteorite: Alteration products in the early solar system. Am. Mineral. 2018, 103, 1918-1924. [CrossRef]

88. Sharygin, V.V.; Yakovlev, G.A.; Wirth, R.; Seryotkin, Y.V.; Sokol, E.V.; Nigmatulina, E.N.; Karmanov, N.S.; Pautov, L.A. Nataliakulikite, $\mathrm{Ca}_{4} \mathrm{Ti}_{2}\left(\mathrm{Fe}^{3+}, \mathrm{Fe}^{2+}\right)\left(\mathrm{Si}, \mathrm{Fe}^{3+}, \mathrm{Al}\right) \mathrm{O}_{11}$, a new perovskite-supergroup mineral from Hatrurim Basin, Negev Desert, Israel. Minerals 2019, 9, 700. [CrossRef]

89. Xu, H.; Lee, S.; Xu, H. Luogufengite: A new nano-mineral of $\mathrm{Fe}_{2} \mathrm{O}_{3}$ polymorph with giant coercive field. Am. Mineral. 2017, 102, 711-719. [CrossRef]

(C) 2020 by the authors. Licensee MDPI, Basel, Switzerland. This article is an open access article distributed under the terms and conditions of the Creative Commons Attribution (CC BY) license (http://creativecommons.org/licenses/by/4.0/). 